\title{
Geometry and kinematics of the Baza Fault (central Betic Cordillera, South Spain): insights into its seismic potential
}

\author{
$\begin{array}{llll}\text { I. Medina-Cascales } & & \text { I. Martin-Rojas } & \\ & \text { F.J. García-Tortosa } & & \text { J.A. Peláez } \\ & & \text { P. Alfaro }\end{array}$ \\ 'Departamento de Ciencias de la Tierra y del Medio Ambiente, Universidad de Alicante \\ 03690, San Vicente del Raspeig, Alicante, Spain. \\ Medina-Cascales E-mail: ivan.medina@ua.es; Martin-Rojas E-mail: ivan.martin@ua.es; \\ Alfaro E-mail: pedro.alfaro@ua.es \\ 2Departamento de Geología, Universidad de Jaén \\ Campus Las Lagunillas, 23071 Jaén, Spain. E-mail: gtortosa@ujaen.es \\ ${ }^{3}$ Departamento de Física, Universidad de Jaén \\ Campus Las Lagunillas, 23071 Jaén, Spain. E-mail: japelaez@ujaen.es
}

\begin{abstract}
The geometry and kinematics of active faults have a significant impact on their seismic potential. In this work, a structural characterization of the active Baza Fault (central Betic Cordillera, southern Spain) combining surface and subsurface data is presented. Two sectors are defined based on their surface geometry: a northern sector striking $\mathrm{N}-\mathrm{S}$ to NNW-SSE with a narrow damage zone and a southern sector striking NW-SE with a wide damage zone. A kinematic analysis shows pure normal fault kinematics along most of the fault. Geometric differences between the northern and southern sectors are caused by i) a heterogeneous basement controlling the fault geometry at depth and in the cover; ii) different orientations of the Baza Fault in the basement with respect to the regional extension direction and iii) interaction with other active faults. We use this structural characterization to analyse the segmentation of the Baza Fault. According to segmentation criteria, the entire Baza Fault should be considered a single fault seismogenic segment. Consequently, the seismic potential of the fault is defined for a complete rupture. Magnitude for the $M_{\max }$ event is calculated using several scale relationships, obtaining values ranging between Mw 6.6 and Mw 7.1. Recurrence times range between approximately 2,000 and 2,200 years for $M_{\max }$ events and between 5,300 and 5,400 years for palaeo-events. A geodetic scenario modelled for an $M_{\max }$ event of Mw 6.7 shows permanent vertical displacements of more than $0.40 \mathrm{~m}$ and an overall WSW-ENE extension during entire ruptures of the Baza Fault.
\end{abstract}

\begin{tabular}{|l|l}
\hline KEYWORDS & Normal fault. Active tectonics. Fault geometry. Seismogenic characterization.
\end{tabular}

\section{INTRODUCTION}

Description and interpretation of the structure of fault systems is essential to better understand and predict their behaviour and is one of the first steps in its seismological and palaeoseismological characterization (e.g. Cowie et al.,
2012; Lezzi et al., 2018; Mildon et al., 2016; Rockwell et al., 2009). The geometric and kinematic features of an active fault influence its seismogenic potential (e.g. Boncio et al., 2004; De Martini et al., 1998; Pace et al., 2016; Wells and Coppersmith, 1994; Wesnousky, 1986), as these features control the propagation of fault ruptures during seismic events

(C) I. Medina-Cascales, I. Martin-Rojas, F.J. García-Tortosa, J.A. Peláez, P. Alfaro, 2020 CC BY-SA 
and hence the magnitude of the event. This is the reason why defining along-strike structural heterogeneities and the tip lines of a fault is essential to fault segmentation (e.g. Boncio et al., 2004; Crone and Haller, 1991; Field et al., 2015; Wesnousky, 2006), i.e. to constrain potential rupture lengths during future earthquakes. The geometric pattern of a fault system also has a major control on seismogenic processes (e.g. Pace et al., 2002; Rice and Cocco, 2007; Scholz, 2002). This characterization of the seismic potential of active faults is a fundamental step in Probabilistic Seismic Hazard Assessment (PSHA) studies. Moreover, geometric and kinematic features of normal fault systems are also important for other disciplines, such as for the analysis of faulted oil, water or mineral reservoirs (e.g. Bense and Person, 2006; Fairley 2009; Folch and Mas-Pla, 2008; Manzocchi et al., 2010; Wibberley et al., 2017).

The Baza Fault (BF) is one of the most active faults in the central Betic Cordillera (southern Spain, Fig. 1). The
1531 AD Baza earthquake ( $\left.\mathrm{I}_{\mathrm{IMS}}=\mathrm{VIII}-\mathrm{IX}\right)$ (MartínezSolares and Mezcua, 2002), the most destructive event reported in this region, occurred on this fault (Alfaro et al., 2008). This event was responsible for 310 deaths and severe damage in the towns of Baza and Benamaurel (Olivera Serrano, 1995). This fault was also responsible for numerous low-magnitude events during historical and instrumental periods (Spanish Instituto Geográfico Nacional (IGN) catalogue; Martínez-Solares and Mezcua, 2002). The seismogenic potential of the BF has been estimated by previous studies (e.g. Sanz de Galdeano et al., 2012), but new, more detailed fault data (particularly about fault geometry) are required for proper characterization. Moreover, new tools were developed in recent years (e.g. Chartier et al., 2019; Pace et al., 2016; Toda et al., 2011) that use the fault data (fault geometry and kinematics) that define the seismogenic potential to estimate parameters necessary for PSHA.

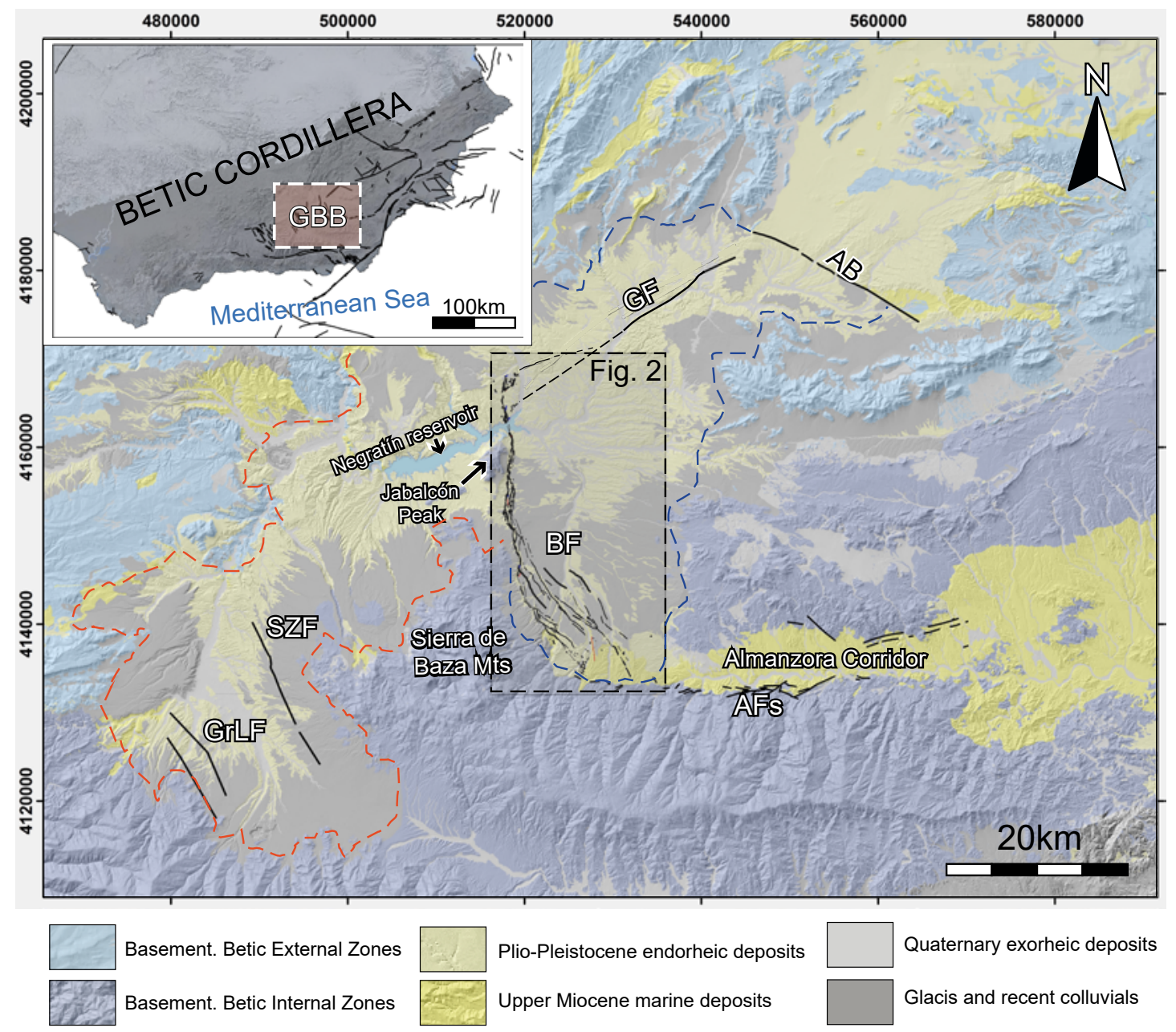

FIGURE 1. Geological map of the Guadix-Baza Basin (GBB). The red dashed line indicates the Guadix subbasin limits. The blue dashed line indicates the Baza subbasin limits. Black lines are the main active structures in the basin. BF: Baza Fault, GF: Galera Fault, AFs: Almanzora Faults, AB: Alfahuara-Botardo structure, SZF: Solana de Zamborino Faults, GrLF: Graena-Lugros Fault. The inset shows the location of the GBB in south-central Spain. 
In this paper, we carry out a structural and seismogenic characterization of the BF. By means of its structural characterization, based on both surface and subsurface data, we define the geometry (length, dip, strike, width) and kinematics of the fault system. Furthermore, we identify, describe and explain the along-strike variations in these parameters. For the surface analysis of the fault geometry, we develop a 1:5,000 scale geological map that includes both the traces of the $\mathrm{BF}$ and the lithostratigraphic units offset by the fault. For the description of the subsurface geometry, we use both gravity (Alfaro et al., 2008) and seismic surveys (Haberland et al., 2017). The kinematic analysis is based on measurements of kinematic indicators, such as slickenlines, joints and veins. Using these geometric and kinematic data, we characterize the seismogenic potential and segmentation of the BF, defining its maximum expected magnitude, mean recurrence times and a geodetic rupture scenario.

\section{GEOLOGICAL SETTING OF THE BAZA FAULT}

The western Mediterranean region is characterized by the oblique NNW-SSE convergence of the Nubian and Eurasian plates (approximately 5-6mm/year, DeMets et al., 2010; Nocquet, 2012) since the Late Miocene. Under this general geodynamic context, regional NNW-SSE shortening (Galindo-Zaldívar et al., 1993; Herraiz et al., 2000; Sanz de Galdeano and Alfaro, 2004) and orthogonal ENE-WSW extension (Galindo-Zaldívar et al., 2015) take place. In the central Betic Cordillera, ENE-WSW regional extension, ranging between 2.1 and $3.7 \mathrm{~mm} / \mathrm{yr}$ (Pérez-Peña et al., 2010; Serpelloni et al., 2007; Stich et al., 2007), is accommodated by NNW-SSE-striking normal faults (Galindo-Zaldívar et al., 1989, 1999; Sanz de Galdeano et al., 2012, 2020). The BF (Fig. 1) is the easternmost active normal fault accommodating this regional extension in the central Betic Cordillera. Its long-term vertical slip rate ranges from 0.2 to $0.5 \mathrm{~mm} / \mathrm{yr}$, using the displaced glacis (ca. 500Kyr) as marker (García-Tortosa et al., 2011; Sanz de Galdeano et al., 2012).

The active BF (Figs. 1; 2) is a 40km-long normal fault striking $\mathrm{N}-\mathrm{S}$ to $\mathrm{NW}-\mathrm{SE}$ and dipping $55 \pm 10^{\circ} \mathrm{E}$ (Alfaro et al., 2008; Haberland et al., 2017; Sanz de Galdeano et al., 2012). Previous studies proposed that normal faulting initiated in the Late Miocene (ca. 8Myr) (García-García et al., 2006). The BF is responsible for a total throw of more than $2000 \mathrm{~m}$ and for a half graben in its hanging wall (Alfaro et al., 2008; Haberland et al., 2017). The surface expression of the BF consists of a fault array whose width and number of fault strands vary along strike. Fault strands with larger displacements within this fault array define a footwall block, a central block and a hanging wall block (Medina-Cascales et al., 2019).
The BF is not the only active fault in the region (Fig. 1). The ENE-WSW regional extension of the central Betic Cordillera is mainly accommodated by N-S to NW-SE normal faults, subperpendicular to the extension direction (e.g. BF, Solana de Zamborino Fault, Graena-Lugros Fault or the Granada fault system; Galindo-Zaldivar et al., 1989, 2015; Gil et al., 2002; Ruiz et al., 2003; Sanz de Galdeano et al., 2012, among others). Deformation also leads to the formation of strike-slip faults subparallel to the extension direction (Fig. 1), such as the left-lateral Galera Fault or the Almanzora Corridor fault system (Galindo-Zaldívar et al., 2015; García-Tortosa et al., 2007, 2011; Guerra-Merchán, 1992; Martínez-Martínez et al., 2006; Pedrera, 2006, 2008, 2012).

The $\mathrm{BF}$ is the main active structure of the Guadix-Baza Basin (GBB) (Fig. 1), which is the largest intramontane Neogene-Quaternary basin of the Betic Cordillera (Vera, $1970 \mathrm{a}, \mathrm{b})$. The sedimentary infill of the basin consists of Upper Miocene marine deposits and Pliocene-Quaternary continental sediments (e.g. García-Aguilar and Martín, 2000; García-Aguilar and Palmqvist, 2011; Gibert et al., 2007a, b; Guerra-Merchán, 1992; Peña, 1979, 1985; Soria et al., 1987; Vera, 1970a, b; Vera et al., 1994; Viseras, 1991), representing one of the most continuous successions of continental Plio-Pleistocene sediments in Europe. The GBB was a continental endorheic basin from the Lower Pliocene until the Middle Pleistocene (García-Tortosa et al., 2008, 2011; Gibert et al., 2007a, b), allowing the preservation of a continuous palaeogeographic, palaeoclimatic and fossiliferous record in the region. During this endorheic stage, an extensive depositional-erosive glacis developed in the GBB. From the Middle Pleistocene on (ca. 500kyr; Díaz-Hernández and Julià, 2006; García-Tortosa et al., 2011; Scott and Gibert, 2009), the basin became exorheic. During this exorheic stage, erosional processes dominated the basin (Calvache and Viseras, 1997; Pérez-Peña et al., 2009) and sedimentation was constrained in marginal alluvial fans, valley bottoms, and fluvial terraces (GarcíaTortosa et al., 2011).

The BF controls the geometry, the accommodation space and the different sedimentary environments in the GBB (García-Tortosa et al., 2008, 2011). The BF divides the GBB into two domains (Figs. 1; 2): the Baza subbasin in the eastern sector and the Guadix subbasin in the western sector (Alfaro et al., 2008). Subsidence related to the downthrow of the BF was responsible for the development of a lacustrine sedimentary environment in the eastern Baza subbasin. Conversely, uplift related to the upthrow of the BF produced the onset of fluvial and alluvial sedimentary environments in the western Guadix subbasin.

Since the Late Miocene, the activity of the BF has controlled the sedimentary environments in the Guadix-Baza basin, 


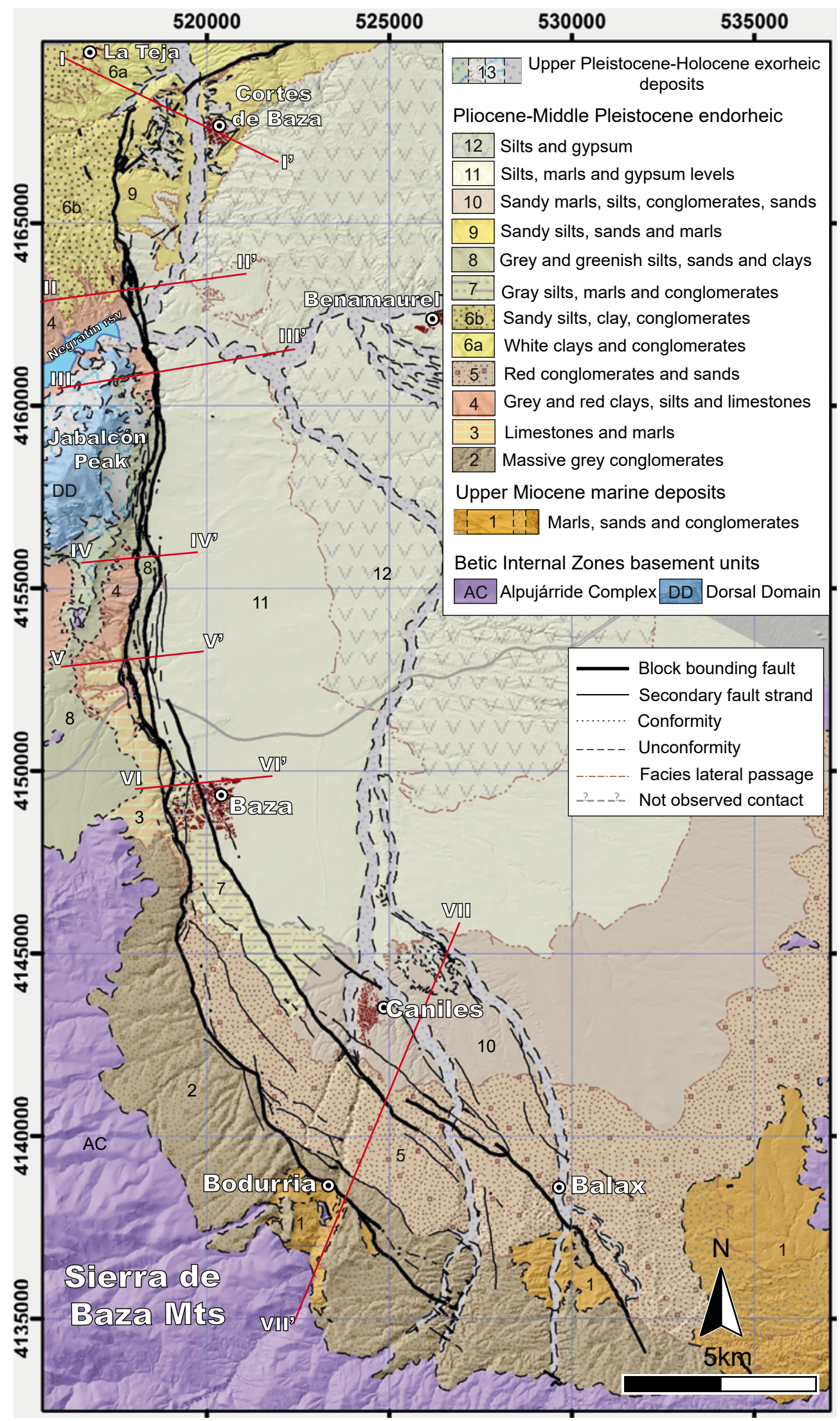

FIGURE 2. Geological map of the Baza Fault and the study area. Red lines show the location of the geological cross sections in Figure 6. 
juxtaposing different facies that outcrop on the different fault blocks. In addition, the development of a lake in the Baza subbasin during Plio-Pleistocene times resulted in a concentric distribution of the sedimentary environments, leading to lateral changes in facies from the borders to the middle of the subbasin (Gibert et al., 2007a). In this work, we define a series of informal lithostratigraphic units (Fig. 3) whose ages are based on previous stratigraphic and palaeontological studies.

The basement of the GBB is highly heterogeneous, as it consists of three different tectonostratigraphic domains (Figs. 1;2; 3). The basement extending south of Baza city consists of Triassic metamorphic rocks of the Alpujarride Complex (Figs. 1; 2; 3) (e.g. García Dueñas et al., 1992; Orozco and Alonso-Chaves, 2002) of the Betic Internal Zones. These rocks are grouped in several stacked tectonic units, each one consisting of a basal meta-detrital formation and an overlying meta-carbonate formation (Delgado, 1978; Delgado-Salazar et al., 1978; MartinRojas et al., 2009, 2012). Basement between the North of Baza city and south of the Negratín Reservoir is made up of a homogeneous carbonate succession, Jurassic in age, belonging to the Frontal Units (Martín-Algarra et al., 2004) of the Betic Internal Zones (Figs. 1; 2; 3). Basement north of the Negratín Reservoir is formed by a sedimentary succession of Mesozoic carbonates and marls belonging to the Betic External Zones (Figs. 1; 3) (Azéma et al., 1979; García-Hernández et al., 1980).

Unconformably over the basement lies unit 1 (Fig. 3), formed by the Upper Miocene (uppermost Tortonian, ca. 8Myr) fan delta and shallow marine deposits (GarcíaGarcía et al., 2006; Guerra-Merchán, 1992). After the onset of normal faulting, sedimentary environments were controlled by the BF during the Pliocene and Pleistocene.

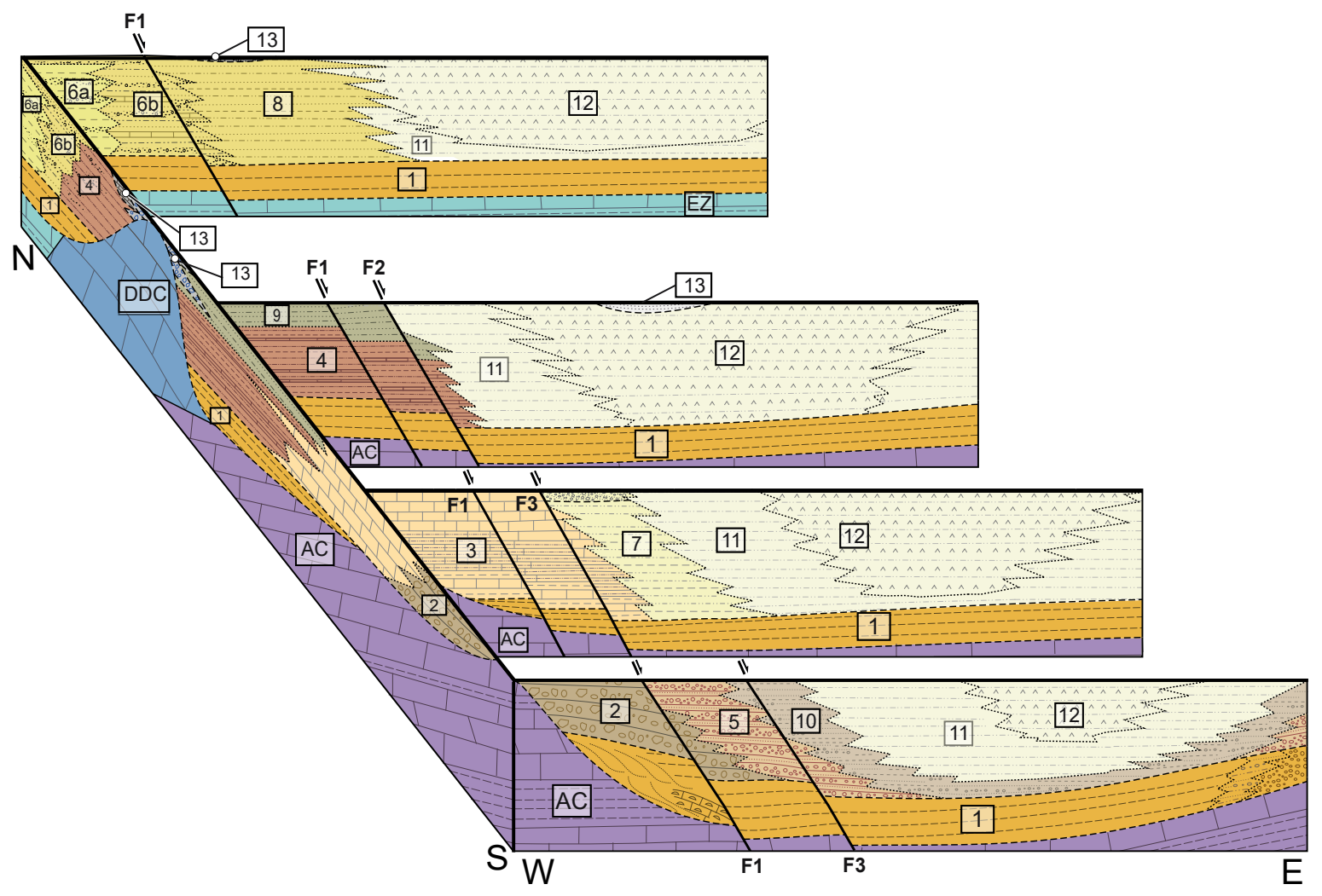

FIGURE 3. Simplified 3D scheme showing the spatial distribution and correlation of the defined lithostratigraphic units along the study area: AC: Alternated meta-detrital and meta-carbonate sediments of the Alpujárride Complex; Betic Internal Zones, Triassic. DD: Massive limestones and dolostones of the Dorsal Units; Betic Internal Zones, Jurassic. EZ: Limestones, marls and sandstones; Betic External Zones, Jurassic-Cretaceous. 1: Marls, sands, conglomerates, reefal limestones; marine and fan delta deposits, Late Tortonian. 2: Massive, cemented conglomerates; proximal alluvial fan, Late Miocene-Early Pliocene. 3: Limestones and marls; lacustrine, Early Pliocene. 4: Grey and red silts, clays, limestones and conglomerates; distal alluvial fan-marginal lacustrine, Pliocene. 5: Red conglomerates and sands; alluvial fan, Pliocene-Early Pleistocene. 6a: White clays and conglomerates; alluvial fan, Pliocene-Early Pleistocene. 6b: Sandy silts, clays, conglomerates and limestone levels; alluvial fan, Pliocene-Early Pleistocene. 7: Grey silts with marl levels and conglomerates on top; lacustrine and fan-delta, Pliocene-Early Pleistocene. 8: Sandy silts, sands and marls; alluvial fan-marginal lacustrine, Pliocene-Early Pleistocene. 9: Dark grey and greenish silts, sands and clays; terminal alluvial fan, Early Pleistocene. 10: Sandy marls and silts with conglomerates and sands; terminal alluvial fan, Pliocene-Early Pleistocene. 11: Layered silts, marls and gypsum levels; lacustrine, Pliocene-Middle Pleistocene. 12: Layered silts and gypsum; distal lacustrine, Pliocene-Middle Pleistocene. 13: Exorheic deposits (travertines, colluvial, fluvial terraces and valley bottom); Late Pleistocene-Holocene. 
Lithostratigraphic units deposited during the endorheic stage can be separated into three groups according to their relative positions with respect to the BF: i) units deposited in the footwall, ii) units deposited in the central block (fault zone) and iii) units deposited in the hanging wall (Fig. 3).

The footwall of the BF (Fig. 2) is dominated in the SW of the study area by Late Miocene to Lower Pliocene proximal alluvial fan deposits (unit 2, Fig. 3), the source of which was the S margin of the basin (García-García et al., 2006; Goy et al., 1989; Guerra-Merchán, 1992). To the N, unit 2 laterally grades to distal fluvial and marginal lacustrine deposits (Fig. 3) of unit 3 (Lower Pliocene, ca. 5 to 4.5Myr; GuerraMerchán et al., 1991; Guerra-Merchán and Ruíz-Bustos, 1992; Ros-Montoya et al., 2017) and units 4 and 9 (Pliocene to Lower Pleistocene, ca. 4 to 2Myr; Agustí et al., 2001). In the northernmost part of the footwall block, Pliocene to Lower Pleistocene distal alluvial fan deposits crop out (unit 6, Fig. 3 ), whose source is the $\mathrm{N}$ margin of the basin (Vera, 1970b).

The central block is dominated to the $\mathrm{S}$ by Late Miocene to Lower Pleistocene alluvial fan facies (units 2 and 5, Fig. 3) (Guerra-Merchán, 1992). To the north, this unit changes laterally to Pliocene to Lower Pleistocene (ca. 2.5Myr) distal alluvial into lacustrine deposits (units 3, 4, 7 and 9, Fig. 3) (Guerra-Merchán et al., 1991; Guerra-Merchán and Ruíz-Bustos, 1992; Peña, 1979).

The hanging wall of the BF (Fig. 2) is dominated in the S and $\mathrm{N}$ of the study area by terminal alluvial fan to lacustrine deposits (units 8, 10 and 11, Fig. 3) (Gibert et al., 2007a; Guerra-Merchán and Ruíz-Bustos, 1992; Peña et al., 1977), Pliocene to Lower Pleistocene in age (ca. 0.8Myr on the top of unit 10). Units 8 and 11 change laterally into the central part of the Baza subbasin to distal lacustrine facies (unit 12, Fig. 3) (Gibert et al., 2007a, b), Pliocene-Middle Pleistocene in age (ca. 2.1 to $0.7 \mathrm{Myr}$ on the top).

Overlaying these endorheic units, Pleistocene-Holocene sediments, such as colluvial slope deposits, travertines, floodplain deposits, and fluvial terraces (unit 13, Fig. 3), were deposited during the exorheic stage of the basin. Some of these recent deposits are offset by the BF (Castro et al., 2018).

\section{Structural characterization of The Baza Fault}

In this section, we describe the structural features of the BF. We focus on macroscale features to describe the map-scale fault geometry and on mesoscale structures to analyse the fault kinematics.

\section{Fault geometry}

The surface geometry of the BF has been defined by means of geological mapping (1:5,000 scale). The resulting map shows the fault traces of the BF and the offset lithostratigraphic units. Mapping has been carried out from field observations combined with aerial photographs and digital elevation models with a resolution of $1 \mathrm{~m}$ per pixel.

The BF is an approximately 40km-long structure, striking NNW-SSE to NW-SE, that crosses almost the entire Baza subbasin (Figs. 1; 2). The BF presents a curved trace in map view (Fig. 2). We divided the BF into two sectors based on the surface geometry of the fault array (Fig. 4A). The $19 \mathrm{~km}$-long northern sector strikes NNW-SSE, and its width varies between 40 and $1,000 \mathrm{~m}$. The southern sector strikes NW-SE, is $21 \mathrm{~km}$ long, and has a width varying between 1 and $7 \mathrm{~km}$.

The subsurface geometry and total cumulative throw of the BF (Fig. 5) have been reconstructed using the available gravity survey carried out by Alfaro et al. (2008). These authors calculate the residual anomaly by subtracting the regional anomaly from that of the Bouguer. Seismic reflection surveys (Haberland et al., 2017) have been also used to support the sub-surface description of the BF. The gravity and seismic profiles have been georeferenced together with our surface data in structural 3D modelling software (MOVEC), developed by Petroleum Experts (PETREX)) to interpolate the 3D geometry of the fault and of the top surface of the Baza subbasin basement (Fig. 5C). This 3D interpolation shows that the general arrangement of the BF at depth is equivalent to the surface expression: a northern sector striking NNW-SSE and a southern sector striking NW-SE. The overall dip of the BF, observable in the seismic profiles (Haberland et al., 2017), is approximately $55^{\circ}$ to the east. The total cumulative throw of the BF can be determined from the available residual gravity anomaly survey (Alfaro et al., 2008) (Fig. 5A, B). The BF presents a maximum displacement of approximately $2,400 \mathrm{~m}$ with two depocenters in the Baza subbasin (Fig. 5B). These maximum displacement values correspond to the central parts of the northern and southern sectors of the BF. A zone with a lower cumulative throw (approximately 2,000m) is observed in the transition zone between the two fault sectors (Fig. 5B).

The surface expression of the BF varies along strike. It consists of a set of closely spaced faults, i.e. fault strands, interconnected between them, whose number ranges from only 1 strand in the $\mathrm{N}$ to more than 10 strands in the $\mathrm{S}$. To define and describe the surface fault array, we grouped the fault strands into two categories according to their displacements and geomorphic expressions. Fault displacement has been estimated using stratigraphic markers and geomorphic features. Fault throw is easily measured when the same stratigraphic marker is observed at both sides of the fault. Stratigraphic markers in the study area record offsets of up to a few tens of metres (maximum valley incision in the area); 


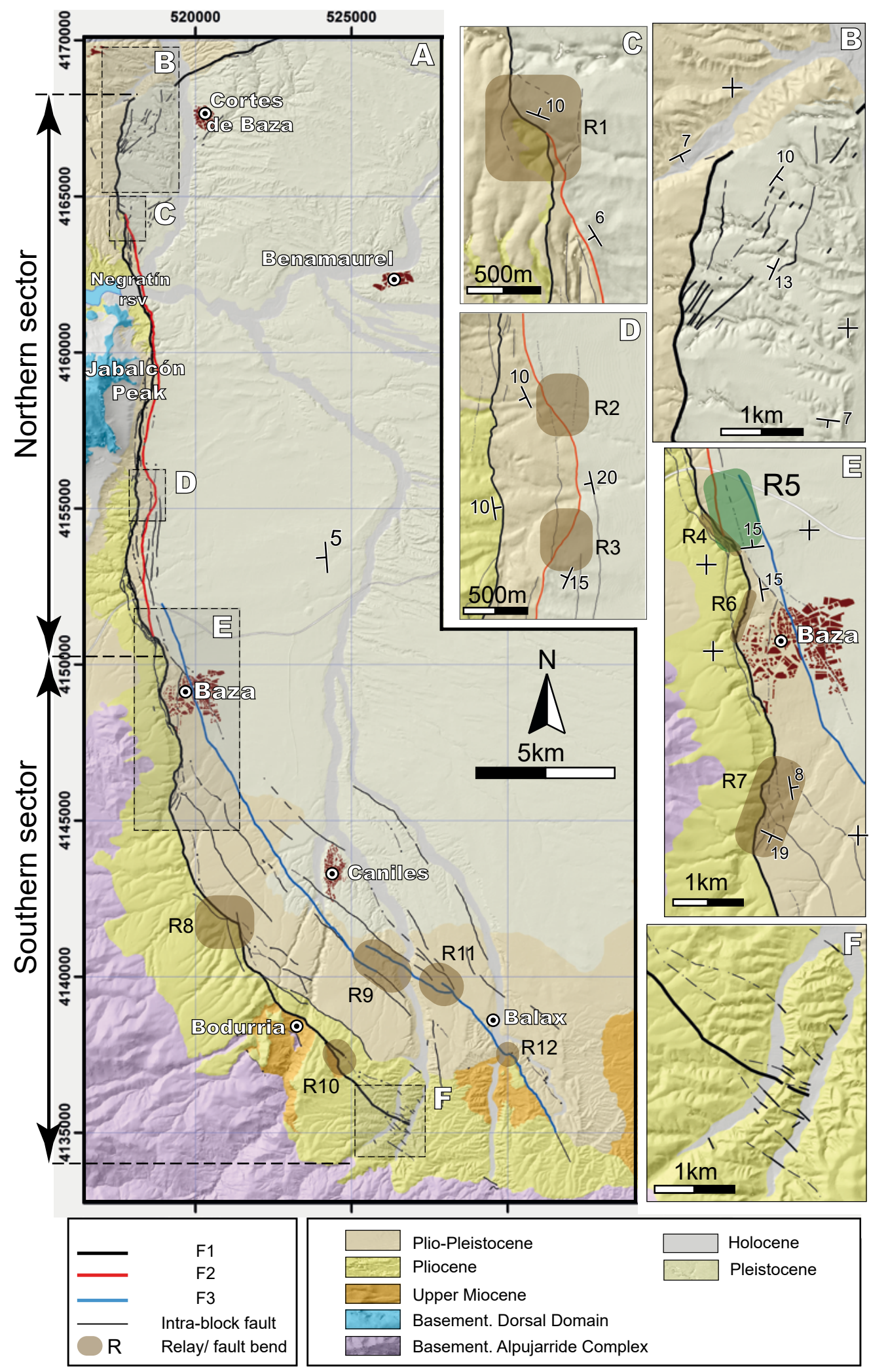

FIGURE 4. A) Surface geometry map of the Baza Fault (BF). Dashed rectangles show the location of the close-ups in B to F. B) Close-up of the northern termination of the BF. C) and D) Close-ups showing the main fault bends in the northern sector of the BF. E) Close-up of the transition area between the northern and southern sectors. F) Close-up of the southern termination of the F1 primary fault. Brown shading represents the main fault bends and relay zones. Green shading represents the relay zone R5 between the F2 and F3 faults. Dark red blobs represent towns. In these maps, stratigraphy is simplified by age. 
A
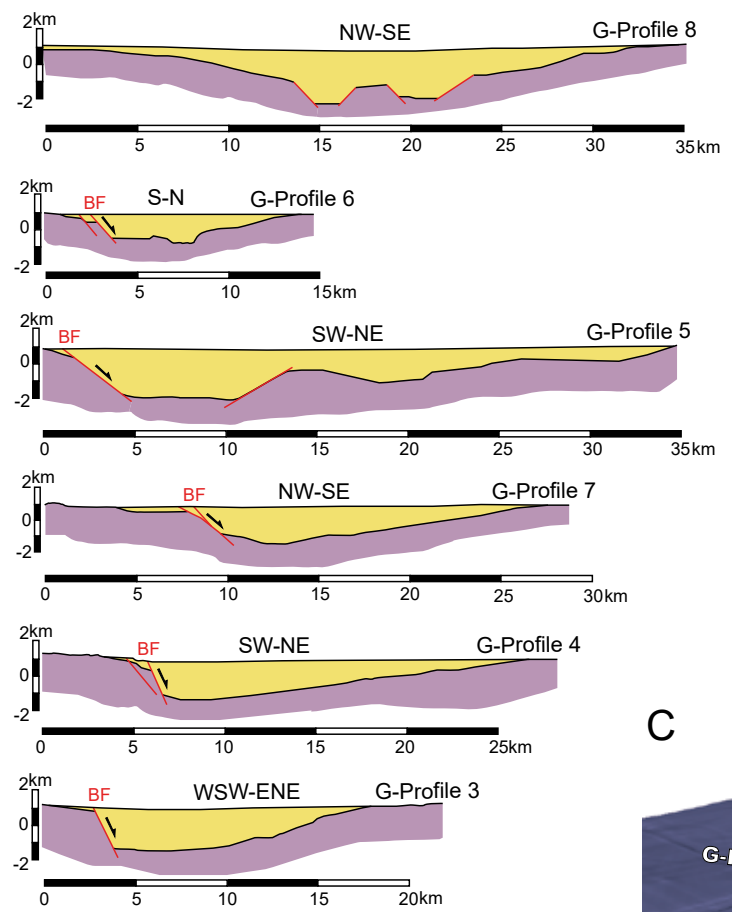

Sedimentary infill

Basement
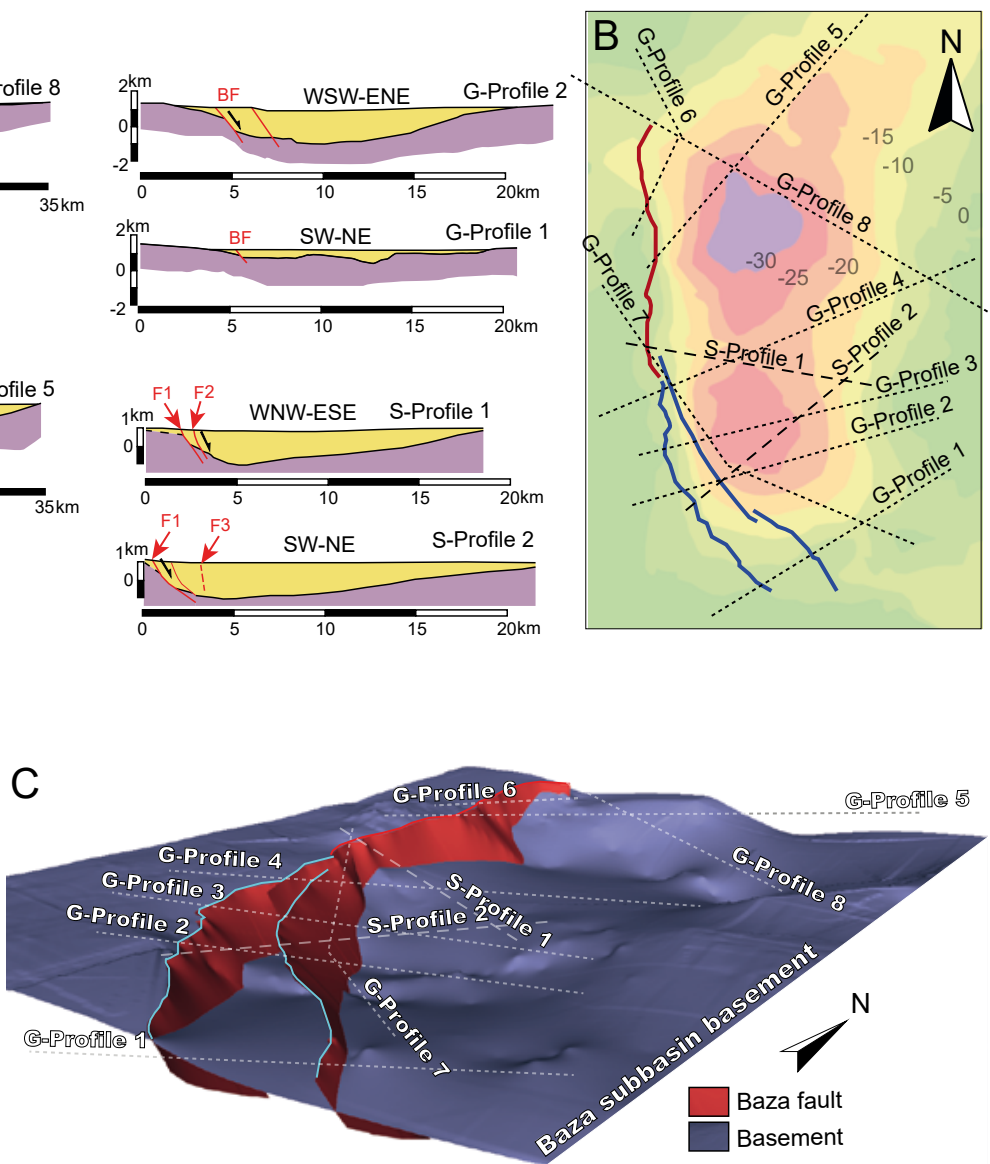

FIGURE 5. A) Cross sections interpreted from the residual gravity anomaly (G-profiles 1 to 8) and seismic (S-profiles 1 and 2) profiles, modified from Alfaro et al. (2008) and Haberland et al. (2017), respectively. We simplified the cross-sections, so they show only two distinct layers of the Baza subbasin: the basement (in purple) and the sedimentary cover (in yellow). Location in B. B) Residual gravity map (contour interval is $5 m$ Gal) of the Baza subbasin, modified from Alfaro et al. (2008). C) 3D model interpolated from the profiles in A. The purple surface is the interpolation of the contact between the basement and the cover. The red surface is the interpolation of the subsurface BF traces. This model shows that the Baza subbasin presents two depocenters. In addition, the model also shows that the subsurface orientation of the BF is NNW-SSE in the northern sector and NW-SE in the southern sector.

consequently, larger fault throws cannot be calculated using stratigraphic markers. We assume that offset is larger than a few tens of metres when two lithostratigraphic units with significantly different ages (age difference larger than 1Ma) are juxtaposed at both sides of a fault. Geomorphic features (the mountain front and fault scarps) record offsets between 1 and tens of metres. With these criteria, two groups of fault strands have been defined: i) block-bounding faults or main faults with larger displacements, i.e. large enough to juxtapose stratigraphic units with an age difference of at least $1 \mathrm{Myr}$ and/or with a geomorphic expression given by several tens of metres high mountain front; ii) intrablock faults or secondary faults with minor displacements, i.e. not large enough to juxtapose stratigraphic units with an age difference of at least $1 \mathrm{Ma}$ and a geomorphic expression given by fault scarps of a few metres high or less (no scarps).

We identified three block-bounding faults: F1, F2, and F3 (Figs. 4A; 6; 7). F1 can be traced all along the BF. It juxtaposes lithostratigraphic units of $4 \mathrm{Myr}$ and $2.5 \mathrm{Myr}$, generating a mountain front up to approximately $140 \mathrm{~m}$. In addition, available seismic profiles (Haberland et al., 2017) show that F1 is the Baza half-graben border fault to the west (Fig. 5A). Consequently, we consider F1 as the fault with the largest displacement in all the BFs. F2 only crops out in the northern sector of the BF, while F3 only appears in the southern sector. F2 and F3 juxtapose lithostratigraphic units of ca. 2.5 and $1 \mathrm{Myr}$ and produce a small mountain front of a few tens of metres high (up to approximately $25 \mathrm{~m}$ ). In addition, seismic profiles show that F2 and F3 present less displacement than that of F1 (Fig. 5A). We interpret F2 and F3 as major fault splays of fault F1. F1, F2 and F3 define the three main fault blocks previously mentioned (Figs. 4; 6): i) The footwall of the BF is located west of F1. ii) A central block is located between F1 and F2 in the northern sector and between F1 and F3 in the southern sector. This central block corresponds to the fault zone of the BF iii) The hanging wall of the BF is located to 

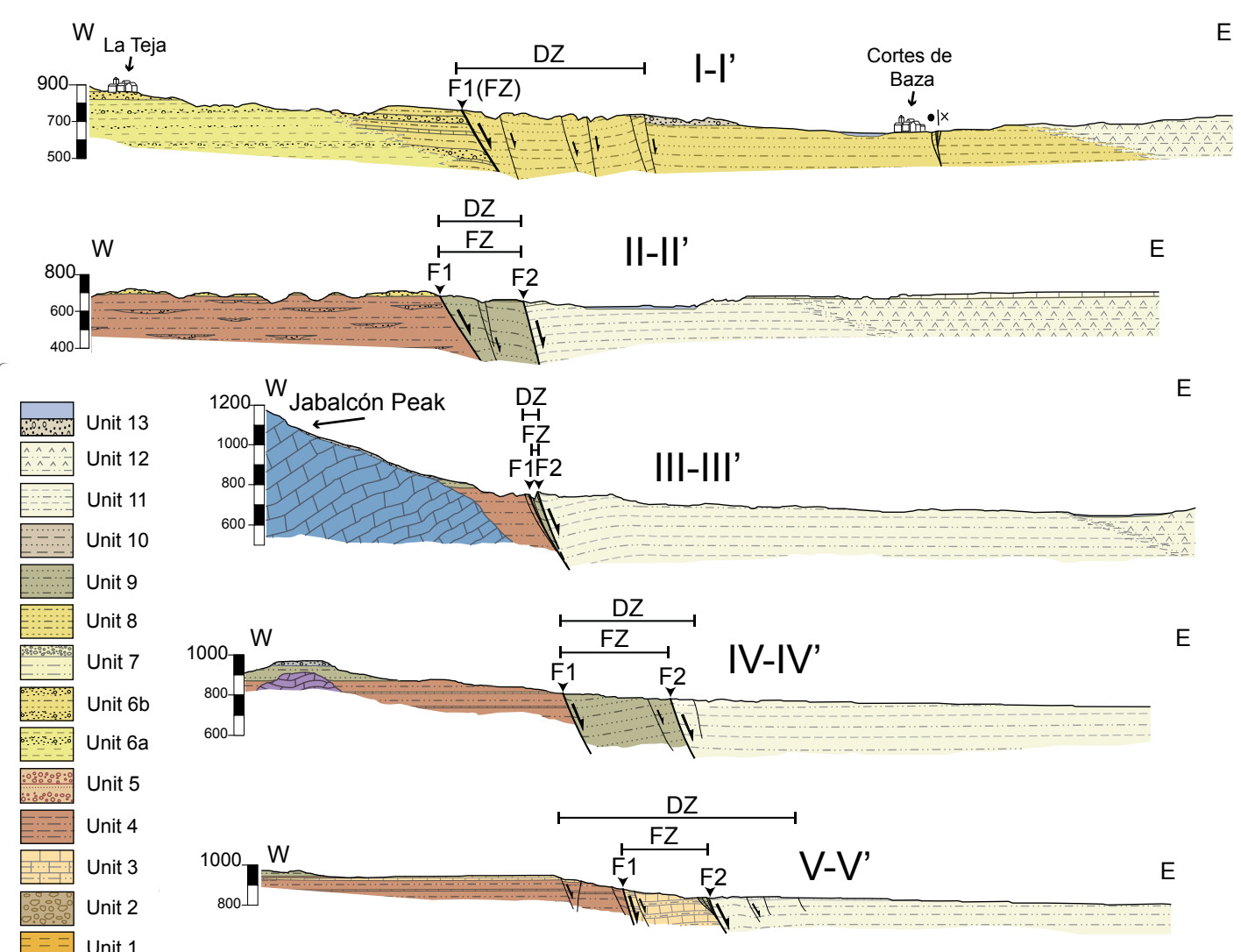

Unit 1

Dorsal Domain

Alpujarride Complex
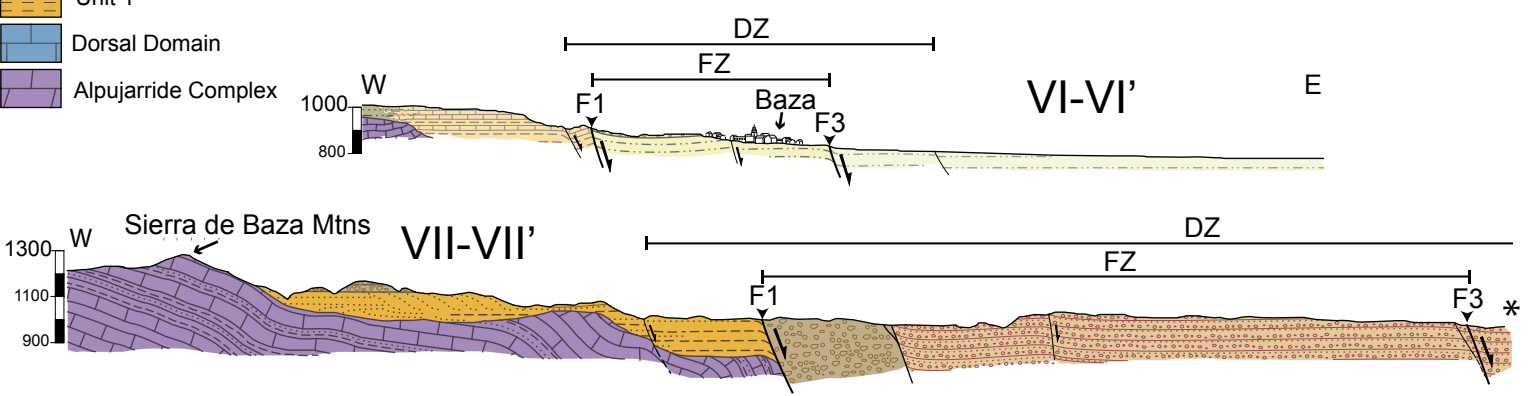

DZ

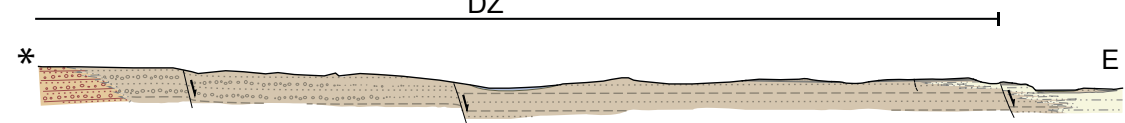

FIGURE 6. Geological cross sections across the BF. Locations are shown in Figure 1. The positions of the block-bounding faults (F1, F2 and F3) are indicated. FZ: fault zone, DZ: damage zone. The widening of the BF along the southern sector is observed in cross sections V-V' to VII-VII'.

the east of F2 and F3. The rest of the BF strands (Fig. 4) are considered secondary, i.e. intrablock faults that internally deform these three main blocks.

\section{Northern sector of the BF}

In the northern sector, the fault zone of the $\mathrm{BF}$ is bounded by $\mathrm{F} 1$ and F2, and deformation concentrates along a narrow damage zone (from 40 to $1,000 \mathrm{~m}$ wide). In this northern sector, the overall strike of the $\mathrm{BF}$ grades from NNW-SSE (approximately N175E) to N-S (Figs. $4 \mathrm{~A} ; 6 ; 7)$.
A closer look reveals that fault strands in the northern sector present local strike variations. These strike variations define fault bends extending tens to hundreds of metres along $\mathrm{F} 1$ (e.g. R1 in Fig. 4C and R4 in Fig. 4E) and F2 (e.g. R2 and R3 in Fig. 4D). Locally, in these areas, beds gently dip perpendicular to the fault bends (e.g. Fig. 4C). Intrablock faults striking parallel to the fault bends are also observed (Fig. 4C, E). These faults extend out of the fault bend striking parallel to the strike of the block-bounding faults (Fig. 4C, D, E). All these structural features evidence that these fault bends are breached relay ramps developed by hard-linked overlapping fault segments: Beds dipping 




FIGURE 7. Structural measurements along the BF. Stereoplots 1 to 5 show the orientations of fault slip surfaces and slickenlines. Almost all the observed slickenlines indicate pure dip slip, i.e. a slip direction varying according to the BF strike. Consequently, the BF presents convergent directions of slip towards the centre of the Baza subbasin. White arrows show the mean slip directions and senses of slip. 
perpendicular to the fault bends represent ramp-like folds, intrablock faults striking parallel to the fault bends conform the damage zone resulting after deformation within the relay ramp, and intrablock faults extending out of the fault bends represent the remains of the original linked fault segments.

Along-strike fault bends lead to width variations in the surface expression of the fault zone. In the northernmost part of the BF, the fault zone is only a few metres wide, as only one block-bounding fault (F1) is recognized (I-I' in Fig. 6). Southwards, F2 branches out from F1 (Fig. 4C); this fact, combined with a right bend in F1, produces a widening of the fault zone up to approximately $200 \mathrm{~m}$ (IIII' in Fig. 6). The fault zone width decreases southwards down to 40-100m (III-III' in Fig. 6) as a consequence of a left bend in F1. After that, successive right bends in both F1 and F2 southwards widen the fault zone up to $600 \mathrm{~m}$ (IV-IV' and V-V' in Fig. 6). In addition to F1 and F2 block-bounding faults, the damage zone in the northern sector of the BF is composed of a variable number of interconnected intrablock faults. These are more abundant (a total of 9 distinct secondary fault strands, at map scale) along the southern part of the northern sector, leading to an approximately $1 \mathrm{~km}$-wide damage zone (Fig. 4A and V-V' in Fig. 6).

\section{Northern termination}

As described above, along the northern termination of the BF, F1 and F2 join approximately $4 \mathrm{~km}$ south of the fault tip (Fig. 4C and I-I' in Fig. 6), and displacement concentrates on a single block-bounding fault (F1). In this northern termination of the $\mathrm{BF}$, the fault strike changes from NNW-SSE (N175E) to SW-NE (N30E) (Figs. 4B; 7). In this area, the geomorphic expression of the $\mathrm{BF}$ is given by a subtle 1-2m-high scarp. In addition, in this northern termination, the $\mathrm{BF}$ juxtaposes stratigraphic units with analogous age (units $6 \mathrm{~b}$ and 8 , Pliocene-Early Pleistocene, Fig. 3 and I-I' in Fig. 6). In this northernmost part of the BF, beds in the hanging wall gently dip to the south (approximately $5-10^{\circ}$ ), parallel to the fault trace (Fig. $4 \mathrm{~B}$ ). At the very end of the northern termination, the F1 fault splays into multiple secondary fault strands, leading to an approximately $800 \mathrm{~m}$-wide damage zone. The northern tip of the BF intersects another fault that extends eastwards striking N70E (Fig. 4A). In this area, minor SW-NE strikeslip faults crop out (Fig. 4B and I-I' in Fig. 6).

\section{Southern sector of the BF}

In the transition between the northern and southern sectors, F2 coalesces with F1 (Fig. 4E). The northern tip point of the F3 fault is located approximately $500 \mathrm{~m}$ north of this coalescence point; consequently, F2 and F3 partially overlap
(R5 in Fig. 4E). This overlap is an approximately 500m-wide and $1000 \mathrm{~m}$-long area where bedding gently dips to the north, parallel to the BF strike. To the south, F3 accommodates a small proportion of the total offset of the BF, juxtaposing units with significantly different ages (Lower Pleistocene, ca. 2.5Myr (unit 7) against Upper Pleistocene, ca. 1Myr (unit 11) deposits; Figs. 3; 4A and VI-VI' in Fig. 6). Consequently, in this southern sector, the fault zone of the BF is bounded by F1 and F3 (Fig. 4). The strike of the BF changes along the southern sector, grading southwards from N165E to N135E. Furthermore, in this sector, deformation is distributed in a wide damage zone that gradually widens southwards from 1 to $7 \mathrm{~km}$ (Fig. 4A; 6).

Again, a closer look reveals that fault strands in the southern sector present strike variations. Along-strike fault bends extending hundreds to thousands of metres are also present along the trace of F1 (e.g. R6 and R7 in Fig. 4E; $\mathrm{R} 8$ and R10 in Fig. 4A). These variations define the trace of $\mathrm{F} 1$ formed by alternate portions striking approximately N165E and N135E (Fig. 4A). Additionally, fault bends tens to hundreds of metres long characterize F3 (e.g. R11 and $\mathrm{R} 12$ in Fig. 4A). All these bends are responsible for the curved traces of faults F1 and F3 in map view (Fig. 4A). Intrablock faults striking parallel to the fault bends are observed (e.g. R7 in Fig. 4E). In addition, intrablock faults extend out of the fault bend striking parallel to the strike of the block-bounding faults (e.g. R8 and R11 in Fig. 4A and R7 in Fig. 4E).

Successive right fault bends and overlaps are responsible for the gradual southward widening of the fault zone along the southern sector (Fig. 4A; 6). To the north of Baza town, the overlap between $\mathrm{F} 2$ and $\mathrm{F} 3$ produces an approximately 600m-wide fault zone (R5 in Fig. 4E and VI-VI' in Fig. 6). Southwards, right bends along F1 produce a widening of the fault zone up to approximately $3 \mathrm{~km}$ (R6 and R7 in Fig. 4A) and even up to $4 \mathrm{~km}$ (R8 to R12 in Fig. 4A and VII-VII' in Fig. 6).

In addition to the F1 and F3 block-bounding faults, the damage zone in the southern sector of the BF is composed of a large number of subparallel intrablock faults. These faults appear mainly in the central block and in the hanging wall. Intrablock faults are more abundant to the south (with 14 observable secondary fault strands), leading to a maximum damage zone width of $7 \mathrm{~km}$ (Fig. 4A and VIIVII' in Fig. 6). Many of these faults are not interconnected at the surface, so faults are soft linked by means of fault overlap.

\section{Southern termination}

Displacement in the southern termination of the BF is distributed into two block-bounding faults (F1 and F3) 
and several intrablock faults (Fig. 2). In this southern termination, F1 presents a geomorphic expression defined by a mountain front approximately $25 \mathrm{~m}$ high and juxtaposes Upper Miocene (Tortonian) unit 1 in the footwall and Upper Miocene-Pliocene unit 2 (Fig. 2 and VII-VII' in Fig. 6) in the hanging wall. Towards the SE, the geomorphic expression of F1 is subtler (approximately $2 \mathrm{~m}$-high scarp), and the fault juxtaposes unit 2 in both the footwall and hanging wall. Farther to the SE, F1 splays into several minor fractures (Fig. 4F). F3 also shows a prominent geomorphic expression (approximately 20m-high mountain front). This geomorphic expression gradually becomes subtler southwards. The F3 fault juxtaposes the same units in both the footwall and the hanging wall (Fig. 2, locally, F3 juxtaposes units 1 and 5 because unit 5 is only approximately $5 \mathrm{~m}$ thick).

\section{Fault kinematics}

In this section, we analyse the BF kinematics from mesoscopic structural features. Slickenlines are the most common kinematic indicators observed on the fault slip surfaces along the BF (Fig. 7). Slickensides and slickenlines are more abundant in the northern sector of the BF, as these features are better preserved in fine-grained lithologies (e.g. unit 9). Most of the observed slickenlines present rakes ranging between 75 and $90^{\circ}$, indicating an almost pure dip slip. Consequently, most of the measured slickenlines indicate slip direction orthogonal to the fault traces. Thus, slip directions in the northern sector of the $\mathrm{BF}$ are in agreement with the overall ENE-WSW regional subhorizontal extension. An exception is observed in the northern termination of the fault, where slickenlines indicate NW-SE slip directions. We postulate that this pattern of slickenlines (Fig. 7) could be related to local perturbations related to the interaction zone between the Galera and the BF. Moreover, strike of fault traces gradually changes along the southern sector of the BF. As consequence, slip directions also grades from ENE-WSW to NE-SW (Fig. 7). We hypothesize that this pattern could also be related to interaction of the $\mathrm{BF}$ with a major active structure, in this case with the Almanzora fault system. The overall convergent pattern of slickenlines observed in the BF (Fig. 7) could be also related to an effect of accommodation of the soft-rocks of the hanging wall, due to the curved geometry of the BF at surface. In addition, scarce oblique slickenlines (rake between 40 and $60^{\circ}$ ) are locally observed in the fault bends (e.g. R12 in Fig. 4A, stereoplot 5 in Fig. 7). These striations indicate oblique kinematics with a main normal component and a minor left-lateral component.

Joints and gypsum veins are abundant throughout the damage zone (Figs. 7; 8A). These fractures are vertical and strike approximately parallel to the BF (Figs. 7; 8A). Thus, vertical veins and joints are subparallel between them but oblique to the fault dip. Fibres within these veins consist of straight gypsum crystals, indicating an opening trajectory perpendicular to the vein surface. These features indicate that no shearing occurred during the veins formation. Consequently, observed joints and veins are in agreement with a subhorizontal extension perpendicular to the fault traces. In zones where the BF offsets fine-grained lithologies (e.g. unit 9), shear zones between slip surfaces show pseudo-SC structures (Fig. 8B). Fault-related folds are also a common feature along the BF (Fig. 8C).

All the above exposed kinematic criteria are in agreement with the results obtained from palaeomagnetic data in the northern sector of the BF (Marcén et al., 2019) and with the ENE-WSW regional extension evidenced by previous authors (e.g. Galindo-Zaldívar et al., 2015).

\section{DISCUSSION OF THE ALONG-STRIKE GEOMETRIC VARIATIONS OF THE BAZA FAULT}

As we described in the section Fault geometry, we have recognized two sectors in the $\mathrm{BF}$ according to the differences in the surface geometry of the fault array (Fig. 4): a northern sector striking N-S to NNW-SSE (N175E) characterized by a narrow damage zone (maximum width of $1 \mathrm{~km})$ and a southern sector that strikes NW-SE (N165E to $\mathrm{N} 135 \mathrm{E}$ ) characterized by a wide damage zone (maximum width of $7 \mathrm{~km}$ ). In this section we discuss these two distinct sectors could be the consequence of three factors: i) a heterogeneous basement, ii) the orientation of the BF with respect to the regional extension and iii) the interaction with other active faults.

i) The BF offsets a heterogeneous basement. The northern sector of the $\mathrm{BF}$ offsets a massive and mechanically homogeneous limestone succession belonging to the Frontal Units of the Betic Internal Zones (Martín-Algarra et al., 2004) (Figs. 2; 3). Consequently, the fault presents a homogeneous dipping geometry and, therefore, a narrow damage zone at the surface (Ferril et al., 2017) (Fig. 9A). The southern sector of the BF offsets a basement belonging to the Alpujarride Complex (Figs. 2; 3), consisting of alternate mechanically heterogeneous layers (e.g. Delgado, 1978; García Dueñas et al., 1992; Orozco and Alonso-Chaves, 2002). As a result, an along-dip step geometry of the BF is expected in this area (Ferril et al., 2017). These fault steps represent asperities to fault movement, resulting in a hanging wall extensive strain that forms contractional or extensional areas where fault networks develop and splay upwards (e.g. Childs et al., 2009; Janecke et al., 2010; Kurt et al., 2013; Legg et al., 2007; Peacock and Anderson, 2012). This led to the formation of the wide damage zone that can be observed on the surface in the BF southern sector (Fig. 9A). 

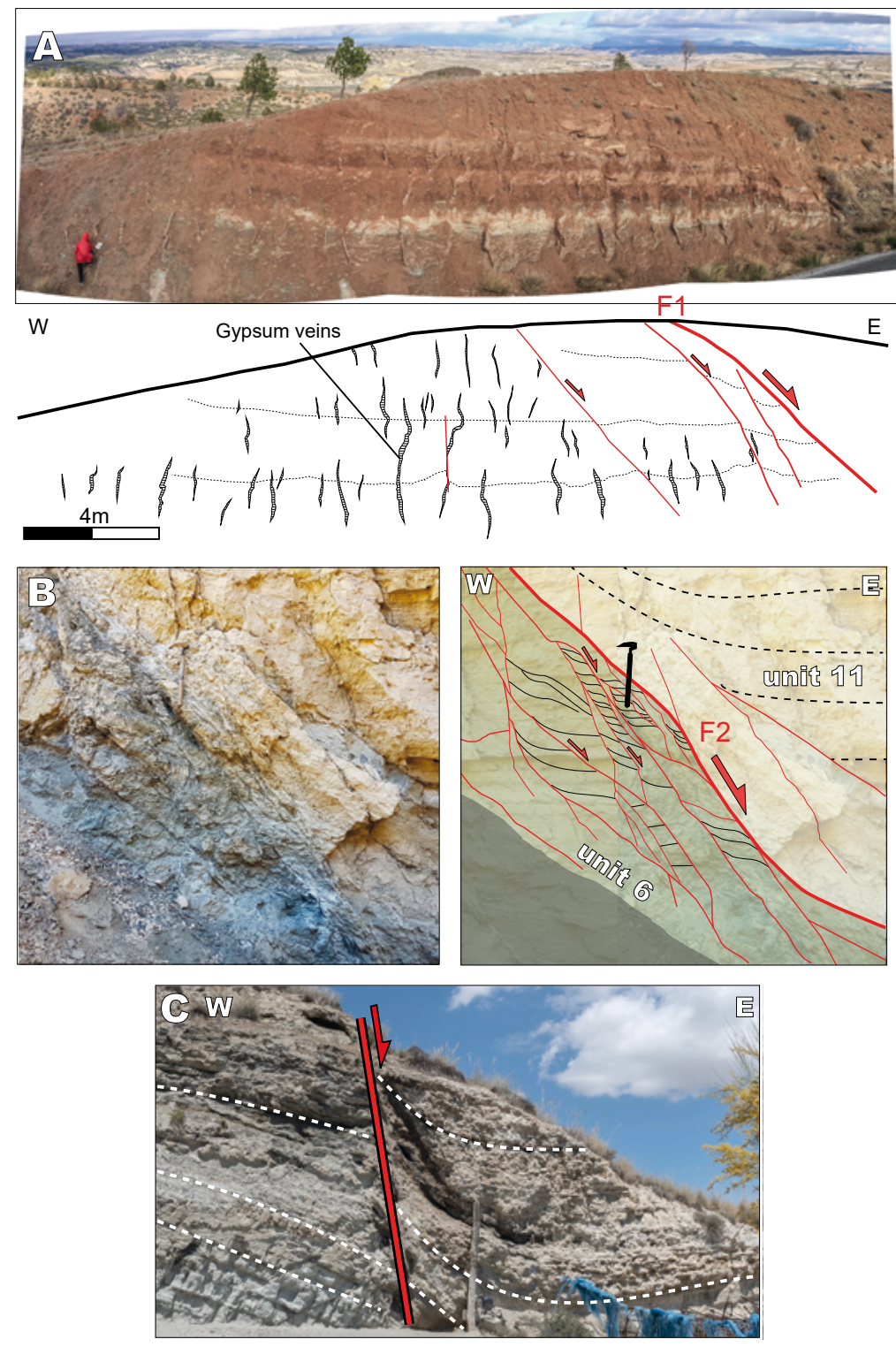

FIGURE 8. A) Panoramic view of vertical gypsum veins associated with F1 in the northern sector of the BF. Veins strike parallel to the BF. Picture location: $518574.869 \mathrm{~m} \mathrm{E,} \mathrm{4160787.898m} \mathrm{N.} \mathrm{B)} \mathrm{Pseudo} \mathrm{SC} \mathrm{structures} \mathrm{related} \mathrm{to} \mathrm{the} \mathrm{F2} \mathrm{fault} \mathrm{zone} \mathrm{in} \mathrm{the} \mathrm{northern} \mathrm{sector} \mathrm{of} \mathrm{the} \mathrm{BF.} \mathrm{The} \mathrm{tool,} \mathrm{shown}$ for scale, is $40 \mathrm{~cm}$ long. Picture location: $518653.962 \mathrm{~m} \mathrm{E}, 4160155.895 \mathrm{~m} \mathrm{~N}$. C) Drag folds related to a secondary fault in the southern sector of the BF. Picture location: 526556.235m E, 4144976.253m N. Projected oordinate system: ETRS 1989, UTM Zone 30N.

ii) The two sectors of the BF present different orientations with respect to regional extension. The orientation of the basement faults with respect to the regional stress field controls the surface geometry of the fault systems when they propagate upwards through the cover (e.g. Bott, 1959; Giba et al., 2012; Jackson and Rotevatn, 2013; Saltzer and Polland, 1992; Whipp et al., 2013). The narrow northern sector is a result of the upward propagation into the sedimentary cover of the NNW-SSE striking BF at the basement (Fig. 5). That is, in this sector, the subsurface BF strikes subperpendicular to the WSW-ENE regional extension (Galindo-Zaldivar et al., 1989, 2015). As a result of this favourable orientation, the surface expression of the $\mathrm{BF}$ in the northern sector consists of a narrow damage zone, subparallel to the basement fault (Fig. 9B) (e.g. Fossen and Rotevatn, 2016; Jackson and Rotevatn, 2013). In contrast, the wider southern sector of the $\mathrm{BF}$ is the result of the upward propagation into the cover of the NW-SE striking basement BF (Fig. 5). That is, in the southern sector, the subsurface $\mathrm{BF}$ is oblique to the regional WSW-ENE extension. Buried faults striking oblique to the extension direction first produce individual fault segments in the cover that strike approximately perpendicular to the extension. More recently, these segments linked up, resulting in a large fault subparallel to the strike of the basement fault 

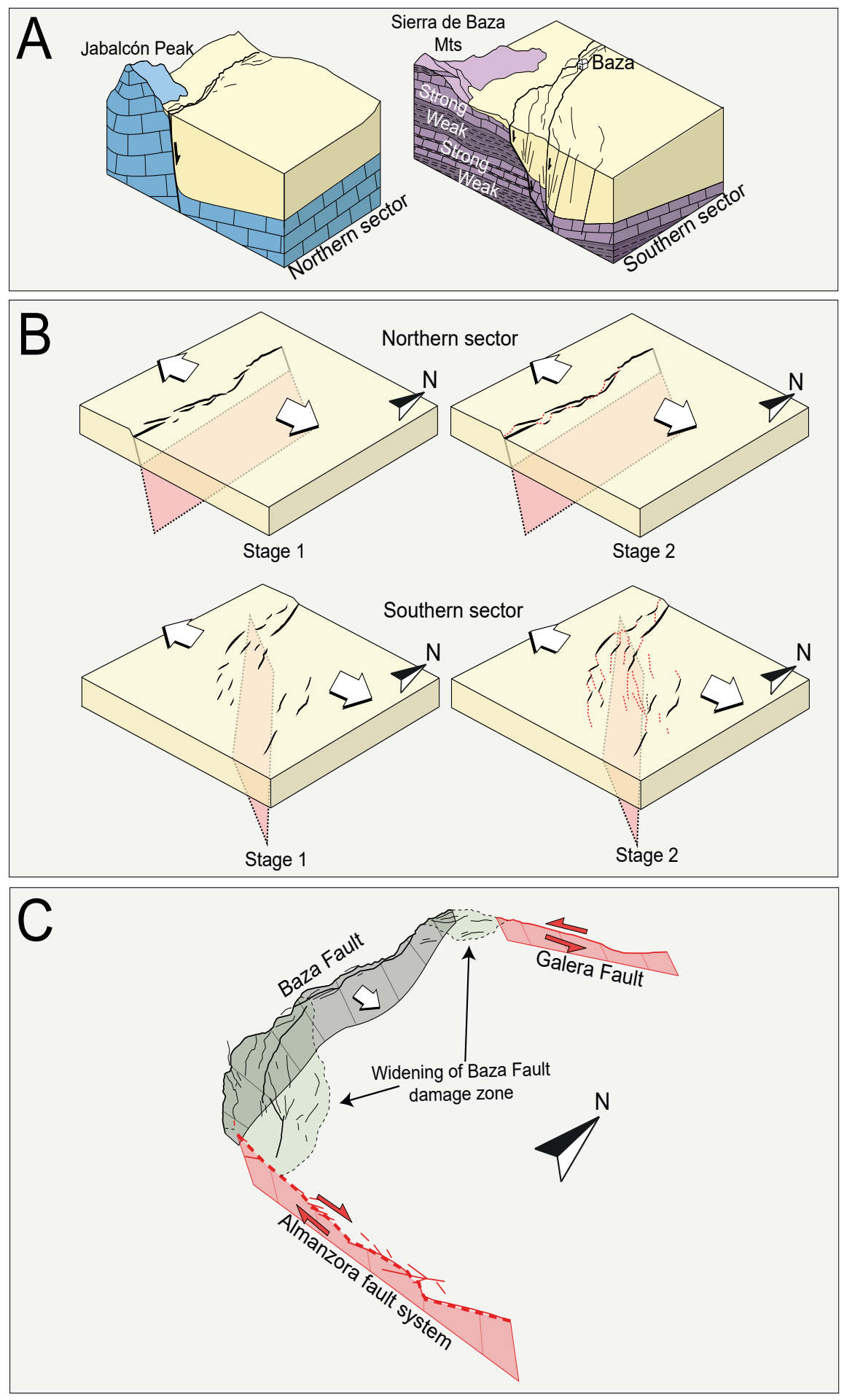

FIGURE 9. Schematic sketch representing how the heterogeneous basement of the Baza subbasin is responsible for along-strike width variations in the BF. In the northern sector, the BF offsets a mechanically homogeneous basement (in blue), so it presents a flat along-dip geometry. This leads to the development of a narrow damage zone in the cover (in yellow). In the southern sector, the BF offsets a basement with significant contrast in competence (in purple), so it presents a step along-dip geometry. This leads to the development of a wide damage zone in the cover (in yellow). B) Schematic sketch representing how the orientation of the basement BF with respect to the regional extension controls the strike and orientation of the fault array on the surface. In the northern sector, the BF at depth is oriented subperpendicular to the regional extension. Consequently, a narrow damage zone, consisting of linked segments perpendicular to the extension, is developed on the surface. In the southern sector, the BF at depth is oblique to the regional extension, so faults perpendicular to the extension (black lines) developed in the cover. In the second stage, these initial faults were linked by segments oblique to the extension (red dotted lines), leading to a wide damage zone on the surface. C) Schematic sketch representing how fault interaction is responsible for along-strike variations in the strike and width of the BF. Interaction between the Galera Fault and the Almanzora fault system led to a widening of the BF damage zone due to the development of interaction damage zones. 
and producing wider damage zones in the cover (Fig. 9B) (e.g. Deng et al., 2017; Fossen and Rotevatn, 2016). This can be observed in the BF southern sector, where fault strands are formed by minor portions oriented approximately perpendicular to the WSW-ENE extension direction (N175E to $\mathrm{N} 165 \mathrm{E}$ ), joined by segments oblique to the extension and subparallel to the basement BF (e.g. F1 in Figs. 2; 4).

iii) The interaction of the BF with other active faults located beyond the fault tip leads to the development of interaction damage zones (sensu Peacock et al., 2016). In these damage zones, deformation is distributed in the rock volume to accommodate displacement and geometric variations along the faults generated by fault interaction (Mouslopoulou et al., 2007; Peacock et al., 2017a, b). The $\mathrm{BF}$ interacts to the northeast with the left-lateral Galera Fault and, to the southeast, with the Almanzora Corridor fault system, which presents overall right-lateral kinematics (Fig. 9C) (Galindo-Zaldívar et al., 2015; García-Tortosa et al., 2011; Guerra-Merchán, 1992; Martínez-Martínez et al., 2006; Pedrera, 2006, 2008). These interactions would be responsible for the change in strike and widening observed in both the northern and southern terminations of the BF.

\section{SEISMOGENIC CHARACTERIZATION OF THE BAZA FAULT}

\section{Is the Baza Fault segmented?}

The above-described northern and southern sectors of the $\mathrm{BF}$ are defined according to the surface geometry of the fault. We discuss in this section whether these two sectors can be considered two seismogenic segments, i.e. whether their differences could act as significant barriers to fracture propagation in past and future earthquakes.

To analyse the segmentation of the BF, we mainly use its geometry, applying the segmentation models defined by
Boncio et al. (2004) and Field et al. (2015) (Table 1). According to Boncio et al. (2004), seismogenic master faults are structures that can be considered substantially continuous at depths of several kilometres, even if in some cases they are divided at the surface in closely spaced structures of minor hierarchical order. Seismogenic master faults are separated from each other by first-order structural or geometric complexities, such as fault gaps, sharp bends, intersecting structures, or en echelon geometries (Table 1). According to the 2013 Uniform California Earthquake Rupture Forecast, Version 3 (UCERF3) model (Field et al., 2015), faults are divided into multiple subsections. These subsections will interact to propagate fault rupture if they fit to a list of criteria based on fault gaps, azimuthal and rake changes, and the Coulomb criterion (Table 1). As previously described, there are azimuth differences between the northern (N-S to N175E) and southern sectors (N165E to $\mathrm{N} 135 \mathrm{E}$ ) of the BF. However, neither the azimuthal changes nor the spacing between F2 and F3 (R5, Fig. 4E) exceed the thresholds established by Boncio et al. (2004) and Field et al. (2015) to be considered rupture propagation barriers. We also apply these criteria to the fault bends (e.g. $\mathrm{R} 1, \mathrm{R} 4$ and R8) and overlaps (e.g. R9) observed along the $\mathrm{BF}$ to check if they can act as propagation barriers within these two sectors, but none of them exceed these thresholds (Table 1).

Kinematics criteria can also be used to define fault segments, i.e. differences in the slip rates or slip direction can act as propagation barriers (e.g. Chartier et al., 2019). Available kinematic data show that there is no significant variation in the slip direction (Fig. 7; Table 1), and differences in fault slip rates between the northern $(0.2-0.5 \mathrm{~mm} / \mathrm{yr}$, GarcíaTortosa et al., 2011) and southern sectors (0.12-0.33mm/ yr, Alfaro et al., 2008) are small and poorly constrained. GPS-derived data seem to indicate different current slip rates in the northern and southern sectors of the BF (Alfaro et al., in press). However, these data are too dispersed to determine if these slip rates clearly define two different

TABLE 1. Geometric segmentation criteria applied to the BF. The first and second columns show the threshold values that each feature must exceed for being considered as a rupture propagation barrier, according to Boncio et al. (2004) and Field et al. (2015), respectively. The third column shows the maximum values measured along the BF for each of these features

\begin{tabular}{lrrr}
\hline & Boncio et al. (2004) & Field et al. (2015) & Baza Fault (max values) \\
\hline Fault gaps & $3-4 \mathrm{~km}$ & $\geq 5 \mathrm{~km}$ & $\sim 100-500 \mathrm{~m}$ \\
Intersecting structures & $4-9 \mathrm{~km}$ & - & $\mathrm{NO}$ \\
Fault bends/junction azimuth & $\geq 60^{\circ}$ & $\geq 60^{\circ}$ & $45^{\circ}$ \\
changes & & - & $1 \mathrm{~km}$ \\
En echelon separations & $2-5 \mathrm{~km}$ & $\geq 60^{\circ}$ & $\sim 40^{\circ}$ \\
Total azimuth change & - & $\geq 560^{\circ}$ & $439^{\circ}$ \\
Cummulative azimuth change & - & $\geq 180^{\circ}$ & $20^{\circ}$ \\
Cummulative rake change & - & &
\end{tabular}


segments or whether there is a gradual change in slip rate. Consequently, according to geometric and kinematic criteria, we propose that despite the two distinct sectors observed in the BF, the entire fault should be considered as a single master seismogenic fault that is not divided into seismogenic segments.

\section{Maximum expected magnitude and mean recurrence times}

To evaluate the seismic potential of the BF, two parameters have been computed: the maximum magnitude $\mathbf{M}_{\max }$ and the mean recurrence time between $M_{\max }$ events, with their respective associated uncertainties. For that, we used different empirical relationships. First, we used the FiSH (Fault into Seismic Hazard) code (Pace et al., 2016). This software enables to characterize and model faults as seismogenic sources for PSHA. It allows to calculate parameters, such as $\mathrm{M}_{\max }$ and mean recurrence times, that serve as inputs to estimate the seismic hazard. These parameters are estimated from fault data, which can include geometrical, seismic and geological information. However, the FiSH code only uses two empirical relationships to calculate $\mathbf{M}_{\max }$ (Leonard et al., 2010; Wells and Coppersmith, 1994). These relations are widely used and conceptually valid. Moreover, an advantage of using FiSH is that it is designed to take into account the uncertainties of the scale relationships, providing the standard deviations for each $M_{\max }$ value. Even so, we decided to calculate $M_{\max }$ using other scale relationships to make a comparison. The chosen regressions are those developed by Stirling et al. (2002) and Wesnousky (2008), as their use is recommended for normal faults.

In the case of the maximum magnitude $\left(\mathrm{M}_{\max }\right)$ that a fault can host, FiSH computes different values from different approaches and/or uses different scale relationships. The code fits these particular values and uncertainties to a global normal distribution, providing a final $\mathbf{M}_{\max }$ mean value and its standard deviation. Input parameters include the total length, mean dip and seismogenic depth of the fault, as well as the maximum recorded event, if available (Table 2). For the BF, fault length and dip were set according to the structural data obtained from the characterization carried out in this work. The seismic depth was set to $15 \mathrm{~km}$ based on the depth of recorded earthquakes in the area (Spanish IGN seismic catalogue, Martínez-Solares and Mezcua, 2002) and the criterion used in this region for other authors (e.g. Galindo-Zaldivar et al., 1997). The 1531 AD Baza earthquake has been considered the maximum recorded event. As this is a historical event, its magnitude has been calculated using a relationship between the maximum macroseismic intensity and moment magnitude (Mw). The latest update of the maximum intensity value for this event is VIII-IX (Martínez Solares and Mezcua, 2002) in the EMS-98 scale (Grünthal, 1998). We used the relationship developed specifically to calculate the Spanish seismic hazard map for the last update of the Spanish seismic-

TABLE 2. Input parameters used in the seismic potential assessment of the BF (upper rows) and resulting values obtained for the $\mathrm{M}_{\text {max }}$ and recurrence times (lower rows)

\begin{tabular}{|c|c|c|c|c|c|}
\hline \multicolumn{6}{|c|}{ Input parameters } \\
\hline \multirow{2}{*}{\multicolumn{4}{|c|}{ Fault data }} & \multicolumn{2}{|c|}{ Paleoearthquakes } \\
\hline & & & & oldest age & youngest age \\
\hline \multicolumn{2}{|c|}{ Fault length: } & $37.5 \mathrm{~km}$ & Baza event: & $1531 \mathrm{AD}$ & $1531 \mathrm{AD}$ \\
\hline \multicolumn{2}{|l|}{ Fault dip: } & $55^{\circ}$ & Paleoevent 7: & 8665 BC & $687 \mathrm{AD}$ \\
\hline \multicolumn{2}{|c|}{ Seismogenic Depth: } & $15 \mathrm{~km}$ & Paleoevent 6: & $13790 \mathrm{BC}$ & $8845 \mathrm{BC}$ \\
\hline \multirow[t]{2}{*}{ Slip-rates } & Min: & $0.2 \mathrm{~mm} / \mathrm{yr}$ & Paleoevent 5: & 15705 BC & $13925 \mathrm{BC}$ \\
\hline & Max: & $0.5 \mathrm{~mm} / \mathrm{yr}$ & Paleoevent 4: & 22223 BC & $17538 \mathrm{BC}$ \\
\hline \multicolumn{2}{|c|}{ Max observed magnitude (Mw): } & $6.3 \pm 0.4$ & Paleoevent 3: & 24229 BC & $22241 \mathrm{BC}$ \\
\hline \multirow{2}{*}{\multicolumn{2}{|c|}{ Last Earthquake: }} & $1531 \mathrm{AD}$ & Paleoevent 2: & 33465 BC & 24347 BC \\
\hline & & & Paleoevent 1: & $45378 \mathrm{BC}$ & $33205 \mathrm{BC}$ \\
\hline \multicolumn{6}{|c|}{ Seismic Potential of the Baza Fault } \\
\hline \multicolumn{6}{|c|}{ Empirical relationship / Distribution } \\
\hline \multirow{4}{*}{\multicolumn{2}{|c|}{ Mmax: }} & \multicolumn{2}{|c|}{ Wells and Coppersmith (1994) } & & $6.6 \pm 0.4$ \\
\hline & & \multicolumn{2}{|l|}{ Stirling et al (2002) } & & 7.1 \\
\hline & & \multicolumn{2}{|l|}{ Wesnousky (2008) } & & 6.9 \\
\hline & & \multicolumn{2}{|l|}{ Leonard (2010) } & & $6.7 \pm 0.4$ \\
\hline \multirow{2}{*}{\multicolumn{2}{|c|}{ Recurrence time (Mmax): }} & \multicolumn{2}{|c|}{ Wells and Coppersmith (1994) } & 2002 years & CV: 1.45 \\
\hline & & \multicolumn{2}{|l|}{ Leonard (2010) } & 2222 years & CV: 1.45 \\
\hline \multirow{2}{*}{\multicolumn{2}{|c|}{ Recurrence time (paleoseismology): }} & \multicolumn{2}{|l|}{ Weibull distribution } & 5370 years & CV: 0.46 \\
\hline & & \multicolumn{2}{|l|}{ Brownian distribution } & 5310 years & CV: 0.46 \\
\hline
\end{tabular}


resistant building code (IGN-UPM, 2013). The result is a Mw 6.3 \pm 0.4 value for the 1531 AD Baza earthquake. The uncertainty of this magnitude value includes both the uncertainty in the intensity assignment and the uncertainty in the used relationship. Considering fault dimensions, this value appears as a low value to the maximum magnitude and does not influence this result too much.

The value of the maximum expected magnitude $\left(\mathrm{M}_{\max }\right)$ obtained using the above-mentioned input parameters ranges between Mw 6.6 \pm 0.4 and $\mathrm{Mw} 6.7 \pm 0.4$, depending on the scale relationship used (Wells and Coppersmith (1994) or Leonard (2010), respectively, Table 2).

As we previously mentioned, we also computed $\mathrm{M}_{\max }$ using other relationships. The obtained values are Mw 7.1 and Mw 6.9, using Stirling et al. (2002) and Wesnousky (2008), respectively (Table 2). The results are very similar to those derived from FiSH if the standard deviations are considered. We interpret the slight differences as result of the different earthquake dataset used by each regression.

The mean recurrence time between $M_{\max }$ events has also been computed, in this case using the criterion proposed by Wesnousky (1986) and Field et al. (1999). The seismic moment is computed for an $\mathbf{M}_{\max }$ event and is collated to the released moment rate obtained from the known slip rate. For this, the $\mathrm{M}_{\max }$ event is considered a characteristic event, i.e. an earthquake that is expected with a certain recurrence interval.

The mean slip rate of the $\mathrm{BF}$ ranges between 0.2 and $0.5 \mathrm{~mm} / \mathrm{yr}$ (García-Tortosa et al., 2011; Table 2). These are long-term slip rates estimated by using the glacis as a geomorphic marker (ca. 500kyr). The resulting mean recurrence time between Mmax events in the BF range between approximately 2,000 and 2,200 years, using the Mmax values obtained from the scale relationships of Wells and Coppersmith (1994) or Leonard (2010), respectively. The coefficient of variation is equal to 1.4 in both cases (Table 2). The uncertainty of this result is very high, showing the influence of both the uncertainty in the knowledge of the slip rate and the uncertainty in the recorded maximum magnitude because, in this case, it was not recorded directly. Regardless, the Mmax value seems to be an upper limit value and may not be a real characteristic earthquake. There is no consistent evidence, considering the palaeoseismological record and historical events, that this magnitude could be previously hosted by the fault.

The available palaeoseismological record (Castro et al., 2018) shows evidence of surface-rupture events in the past. Therefore, the recurrence time for these earthquakes has also been calculated. The surface-rupturing chronology used for this purpose includes eight events that occurred between ca. 45,000 BC and $1531 \mathrm{AD}$, including the historical 1531 AD Baza earthquake (Table 2). According to Castro et al. (2018), the minimum magnitude for the earthquakes represented in the palaeoseismic record for the $\mathrm{BF}$ is around $\mathrm{Mw}$ 6. We have considered both the time and uncertainties (i.e. youngest and oldest year for each occurrence) of each event. Using the FiSH code, these data have been adjusted, using simulations, to well-known temporal distributions. Although all the considered distributions give almost the same results, the Weibull distribution (e.g. Patel et al., 1976) provided the best adjustment. This is an inter-occurrence time distribution that has a scale-invariant hazard function, showing very good agreement in many faults with reported palaeoseismological events (Abaimov et al., 2008). Regardless, the Brownian Passage Time (BPT) distribution (Matthews et al., 2002) gives quite similar results.

The obtained mean recurrence time for the palaeoseismological events using both the BPT and the Weibull distributions is approximately 5,300-5,400 years, respectively. The coefficient of variation is equal to 0.46 (Table 2). It must be highlighted that the obtained result is not the mean recurrence time for $M_{\max }$ but for those surface rupture events that are represented in the palaeoseismological record. These values are similar to 4,750-5,150 years fault-wide earthquake recurrence intervals calculated using Monte Carlo analysis from palaeoseismic data (Castro et al., 2018).

Figure 10 depicts the Probability Distribution Function (PDF) and the Cumulative Distribution Function (CDF) for the adjusted Weibull distribution using the computed parameters. The PDF represents the probability that a new earthquake happens in a certain time after the occurrence of the last one (elapsed time $t$ ), and the CDF represents the probability that a new earthquake happens in a time less than or equal to t. For clarification, the elapsed time since the 1531 Baza earthquake is included.

The above-exposed recurrence times obtained for the $\mathrm{M}_{\max }$ earthquakes using long-term slip-rates and for the available palaeoseismological record are significantly different (2,000-2,200 and 5,300-5,400 years, respectively). This difference could be related to the fact that calculations using long term slip-rates may be overestimated. Long-term slip rates incorporate the seismic displacement, but also the potential aseismic displacement related to creeping processes along the $\mathrm{BF}$ (Sparacino et al., 2020) and the displacement produced by low-magnitude earthquakes with no surface ruptures. On the contrary, recurrence intervals obtained from the palaeoseismological data may be underestimated. Palaeoseismological record of Castro et al. (2018) is obtained from only 2 of the many strands of the BF. In 


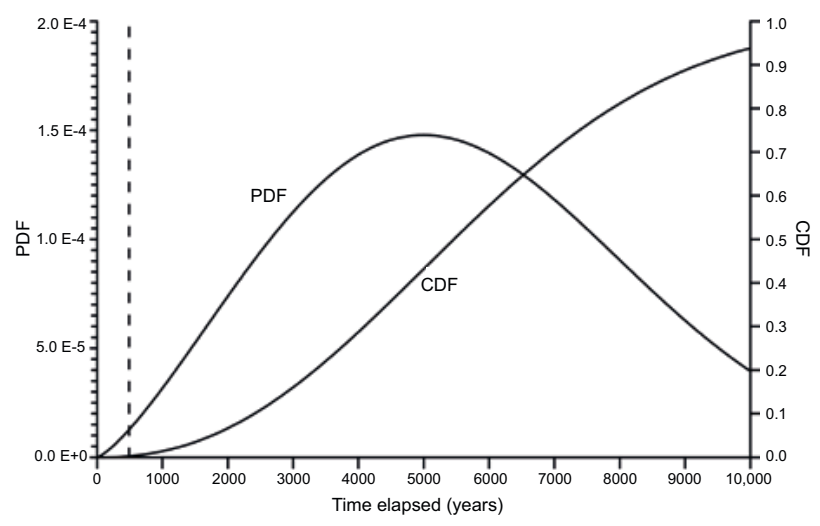

FIGURE 10. Probability Distribution Function (PDF) and Cumulative Distribution Function (CDF) for the BF according to the adjusted Weibull distribution, using the computed recurrence times from the palaeoseismological record. The dashed line indicates the elapsed time since the 1531 Baza earthquake (489 years in 2020).

addition, the paleoearthquake record is intrinsically incomplete, as it is likely that there are more paleoevents that have not been identified in the trenches because of the distributed character of the deformation along the BF strands. This makes that the used palaeoseismic data are not representative for the whole fault. Consequently, we assume that the recurrence times obtained from long-term slip rates represent a minimum value, as they incorporate the displacement produced by creeping and by lowmagnitude earthquakes. On the contrary, recurrence times obtained from the palaeoseismological data represent a maximum value, as they are based on incomplete data.

In conclusion, we suggest that the real recurrence times for the surface-rupturing earthquakes of the BF may be an intermediate value between those obtained from the long-term slip rates (2,000-2,200 years, minimum value) and those obtained from the palaeoseismological record (5,300-5,400 years, maximum value).

\section{Geodetic scenario for the $M_{\max }$ event}

Once the $\mathbf{M}_{\max }$ magnitude earthquake has been estimated, a geodetic scenario for this event has been modelled. This requires the computation of the static displacement (i.e. the permanent displacement caused by a specific earthquake) based on the fault geometry and the modelling of the displacement among the two blocks along the fault plane. To evaluate this scenario, the Coulomb 3.3 code (Toda et al., 2011) was used. This software uses Okada's approach (Okada, 1985, 1992) to model the deformation of an elastic half-space with constant elastic properties. The fault has been modelled as several fault planes, adjusting as well as possible the geometry of the BF.
Given the geometry (total length, dip and seismogenic depth) of the fault, the $M_{\max }$ magnitude has been modelled using a uniform displacement among blocks of $0.65 \mathrm{~m}$, which involves a seismic moment on the order of $1.24 \cdot 10^{26} \mathrm{dyn} \cdot \mathrm{cm}$, i.e. a Mw 6.7 event (sensu Wells and Coppersmith, 1994). A transition zone was used at the edges of the fault to avoid significant discontinuities in the fault displacement, although this does not significantly affect the computed displacement field. The software models an upward movement of the footwall and a downward movement of the hanging wall equal to, in both cases, half of the net slip/displacement.

The obtained results are shown in Figure 11. Vertical and horizontal deformations can be observed jointly, clearly showing the large area affected from a geodetic point of view for such earthquakes. Downward permanent displacements in the hanging wall block reach values that exceed $0.40 \mathrm{~m}$, embracing all the central half of this block. In contrast, upward permanent displacements in the footwall block are on the order of a few centimetres. Two areas of maximum vertical displacement are observed in the hanging wall, one to the $\mathrm{N}$ of Baza town and another to the W of Caniles town (Fig. 11). We interpret these two maximum displacement areas as features derived from the irregularities of the fault trace. Where the fault present curvatures along its trace, maximum vertical displacement areas are developed. Horizontal permanent displacements reach values that exceed $0.20 \mathrm{~m}$ in the footwall block and $0.15 \mathrm{~m}$ in the hanging wall block. Horizontal displacements show a behaviour that globally can be described as an overall WSW-ENE extension. Local variations in this overall trend are observed, especially in the hanging wall block. We postulate that these variations in the direction of the coseismic displacement vectors are related to near-field irregularities related with changes of the fault geometry. In the northern sector of the BF, the horizontal displacement direction varies from NW-SE (approximately $\mathrm{N} 150 \mathrm{E}$ in the Cortes de Baza town) to WSW-ENE (approximately N085E in Baza town) (Fig. 11). In the southern sector, the horizontal displacement direction varies from WSW-ENE (approximately N085E in Baza town, Fig. 11) to SW-NE (approximately N040E close to Caniles town) (Fig. 11).

These results show a typical behaviour of a normal fault (e.g. Kobayashi et al., 2012; Sun et al., 2008) and fit with the geological kinematic data (Fig. 8). This type of displacement maps could help in the design of geodetic networks focused on the study of regional or local deformations in the area. For example, observed local anomalies of the displacement vectors close to the fault, diverging from the overall direction of the regional deformation, indicate that GPS stations should not be installed too close to the fault traces to avoid these local effects. 


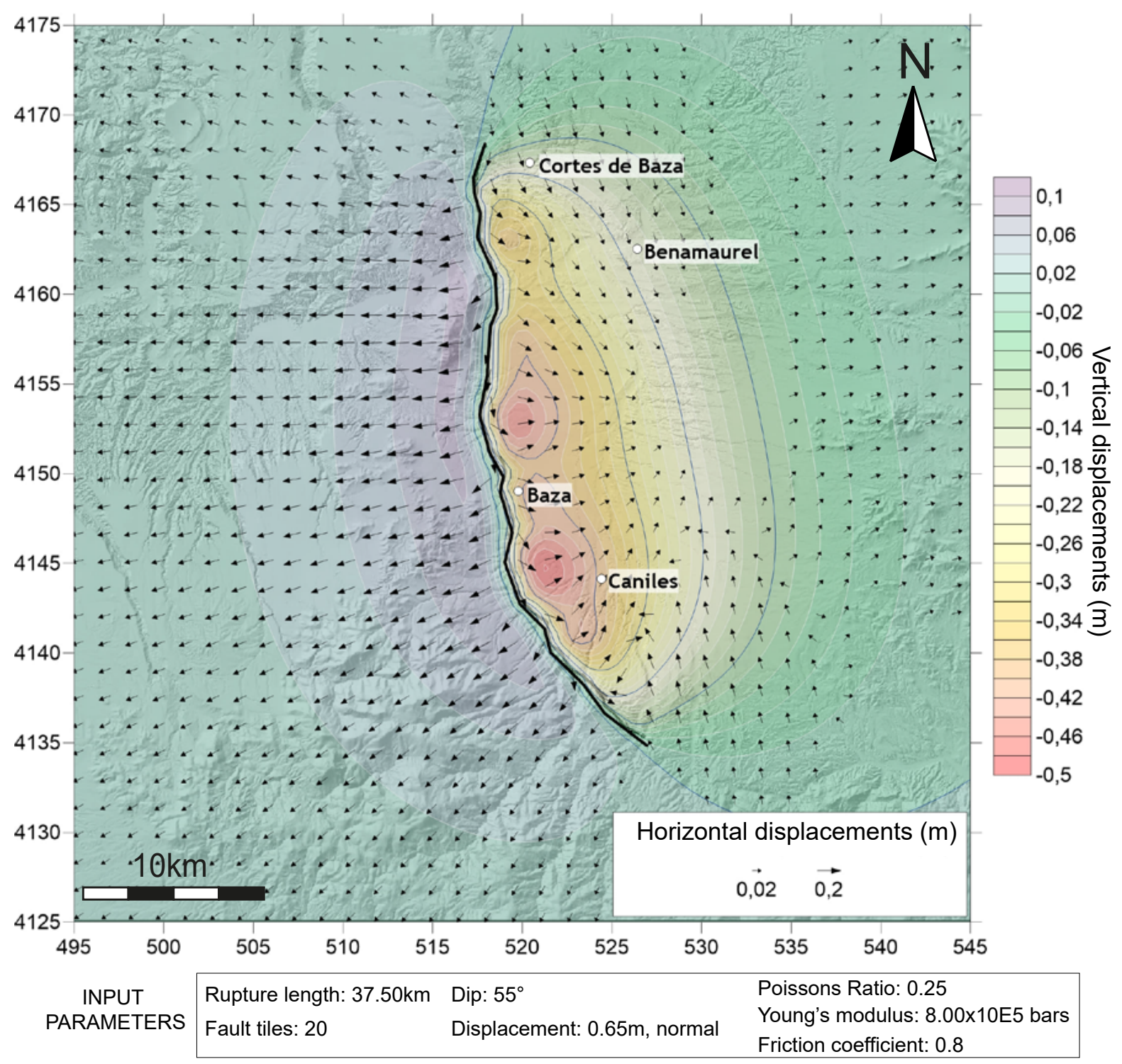

FIGURE 11. Geodetic scenario for the $\mathrm{M}_{\max }$ magnitude earthquake ( $\mathrm{Mw}$ 6.7) showing both vertical (coloured contours) and horizontal (black arrows) permanent deformations. This figure shows a modelled fault trace, not the real one. Input parameters are presented.

\section{CONCLUSIONS}

A structural characterization permits us to consider two different sectors in the BF: i) a northern sector striking $\mathrm{N}-\mathrm{S}$ to NNW-SSE (N175E) characterized by a narrow damage zone (maximum width of $1 \mathrm{~km}$ ) and ii) a southern sector striking NW-SE (N165E to N135E) characterized by a wide damage zone (maximum width of $7 \mathrm{~km}$ ). (Figs. $2 ; 4)$.

The along-strike geometric variation between the northern and southern sectors is caused by i) a different basement in the north and south of the Baza subbasin that controls the fault geometry at depth and thus the geometry of the upwards propagated damage zone in the cover (Fig. 9A); ii) different orientations of the $\mathrm{BF}$ in the basement between the northern and southern sectors with respect to the WSEENE regional extension (Fig. 9B) and iii) the interaction of the $\mathrm{BF}$ with other active faults leads to interaction damage zones near the fault terminations (Fig. 9C). The kinematic analysis (Fig. 7) shows pure normal fault kinematics in most of the BF, except in some fault bends, where the fault presents an oblique slip.

A seismogenic characterization of the $\mathrm{BF}$ is carried out based on the geometric, kinematic, slip rate and seismic data of the BF to discuss fault segmentation and to evaluate the seismic potential of the fault. The BF constitutes a single seismogenic master fault according to geometric and kinematic segmentation criteria. The 
seismic potential of the BF is defined by calculating $\mathrm{M}_{\max }$ and recurrence times using different empirical relations (Table 2). The expected $\mathbf{M}_{\max }$ considering an entire rupture of the $\mathrm{BF}$ ranges between $\mathrm{Mw} 6.6 \pm 0.4$

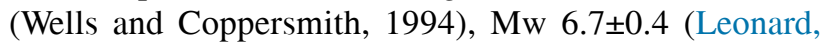
2010), Mw 6.9 (Wesnousky, 2008) and Mw 7.1 (Stirling et al., 2002). Recurrence times between $\mathbf{M}_{\max }$ events range between approximately 2,000 and 2,200 years $(\mathrm{CV}=1.45)$. Furthermore, recurrence times calculated from the palaeoseismological record, using both the BPT and the Weibull distributions, are approximately 5,300 5,400 years $(C V=0.46)$, respectively. We suggest that the actual recurrence times for the $\mathrm{BF}$ may range between the overestimated value obtained from the long-term slip rates (2,000-2,200 years) and the underestimated value obtained from the palaeoseismological record $(5,300$ 5,400 years).

A geodetic rupture scenario has been modelled for an $\mathrm{M}_{\max }$ event of Mw 6.7 (Fig. 11). Vertical permanent displacements are higher in the hanging wall block, reaching values that exceed $0.40 \mathrm{~m}$ in the central part of this block. Horizontal permanent displacements present values that exceed $0.20 \mathrm{~m}$ and $0.15 \mathrm{~m}$ in the footwall and hanging wall blocks, respectively. This scenario shows an overall WSW-ENE extension, which fits with the present geodynamic setting of the central Betic Cordillera. However, local variations in the direction of extension are observed due to the variations in the fault geometry, especially in the hanging wall block.

The results here presented include a detailed analysis of geometrical heterogeneities both in surface but also in deep structural levels of the BF. In addition, a seismogenic characterization is presented based on these new fault data. Both the structural data and the estimation of the seismogenic parameters of the fault will be relevant for future seismic hazard studies in the central Betic Cordillera, considered as one of the most seismically active areas in the Iberian Peninsula. Our results will also be very helpful in the design of geodetic networks, and in studies of upscaling, subsurface imaging, and reservoir modelling of highly complex fault zones in poorly lithified sediments that are presently developing several international research groups in the BF area.

As a final note, and as future worklines, it is worth noting that the realization of palaeoseismological studies in as many faults (or fault strands of a fault system) as possible would be essential in order to improve the accuracy and quality of studies focused in the characterization of seismogenic structures in the region. Moreover, to achieve an accurate characterization of the subsurface geometry of the main active faults in the area, it may be also necessary to carry out detailed geophysical surveys, e.g. seismic reflection profiles, with a proper resolution.

\section{ACKNOWLEDGMENTS}

This work was funded by the research project TASCUB (RTI2018-100737-B-I00) of the Spanish Ministry of Science, Innovation and Universities, the research group VIGROB053 (University of Alicante), the research project AICO/2019/040 of the Generalitat Valenciana (Valencia regional government), and the research group RNM-325 of the Junta de Andalucía (Andalucia regional government). Iván Medina Cascales was funded by Ph.D. contract FPU16/00202 of the Spanish Ministry of Science, Innovation and Universities. Research partially funded by the Programa Operativo FEDER Andalucía 2014-2020-call made by the University of Jaén 2018. In addition to the authors, Julia Castro were also involved in the field campaign. We thank her for active participation and constructive discussions. We would also like to thank the reviewers Octavi Gómez and José Jesús Martínez Díaz, whose suggestions greatly improved the manuscript. The authors gratefully acknowledge the donation of academic licenses of the software MOVEC by Petroleum Experts (PETREX), which were used to develop the 3D model of the BF.

\section{REFERENCES}

Abaimov, S.G., Turcotte, D.L., Shchervakov, R., Rundle, J.B., Yakovlev, G., Goltz, C., Newman, W.I., 2008. Earthquakes: Recurrence and Interoccurrence Times. Pure and Applied Geophysics, 165, 777-795. DOI: 10.1007/s00024-008-0331-y

Agustí, J., Oms, O., Remacha, E., 2001. Long Plio-Pleistocene terrestrial record of climate change and cammal turnover in southern Spain. Quaternary Research, 56(3), 411-418. DOI: https://doi.org/10.1006/qres.2001.2269

Alfaro, P., Delgado, J., Sanz de Galdeano, C., Galindo- Zaldívar, J., García-Tortosa, FJ., López-Garrido, A.C., López-Casado, C., Marín-Lechado, A., Gil, A., Borque, M.J., 2008. The Baza Fault: a major active extensional fault in the central Betic Cordillera (south Spain). International Journal of Earth Sciences, 97, 1353-1365. DOI: https://doi.org/10.1007/ s00531-007-0213-z

Alfaro, P., Sánchez-Alzola, A., Martin-Rojas, I., García-Tortosa, FJ., Galindo-Zaldívar, J., Avilés, M., López Garrido, A.C., Sanz de Galdeano, C., Ruano, P., Martínez, F, Pedrera, A., Lacy, M.C., Borque, M.J., Medina-Cascales, I., Gil, A.J., in press. Geodetic fault slip rates of active faults in the Baza sub-basin (SE Spain). Insights for seismic hazard assessment. Journal of Geodynamics.

Azéma, J., Foucault, A., Foucarde, E., García-Hernández, M., González-Donoso, J.M., Linares, D., López-Garrido, A.C., Rivas, P., Vera, J.A., 1979. Las microfacies del Jurásico y el Cretácico de las Zonas Externas de las Cordilleras Béticas. Publicaciones de. La Universidad de Granda, 83pp.

Bense, V.F, Person, M.A., 2006. Faults as conduit-barrier systems to fluid flow in siliciclastic sedimentary aquifers. Water Resources Research, 42(5), W05421. DOI: https://doi. org/10.1029/2005WR004480 
Boncio, P., Lavecchia, G., Pace, B., 2004. Defining a model of 3D seismogenic sources for Seismic Hazard Assessment applications: The case of central Apennines (Italy). Journal of Seismology, 8, 407-425. DOI: https://doi.org/10.1023/ B:JOSE.0000038449.78801.05

Bott, M.H.P, 1959. The mechanics of oblique slip faulting. Geological Magazine, 96(2), 110-117. DOI: https://doi. org/10.1017/S0016756800059987

Calvache, M.L., Viseras, C., 1997. Long-term control mechanisms of stream piracy processes in southeast Spain. Earth Surface Processes and Landforms, 22(2), 93-105. DOI: https://doi. org/10.1002/(SICI)1096-9837(199702)22:2\%3C93::AIDESP673\%3E3.0.CO;2-W

Castro, J., Martin-Rojas, I., Medina-Cascales, I., García-Tortosa, FJ., Alfaro, P., Insua-Arévalo, J.M., 2018. Active faulting in the central betic Cordillera (Spain): palaeoseismological constraint of the surface-rupturing history of the Baza Fault (central betic Cordillera, Iberian Peninsula). Tectonophysics, 736, 15-30. DOI: https://doi.org/10.1016/j.tecto.2018.04.010

Chartier, T., Scotti, O., Lyon-Caen, H., 2019. SHERIFS: OpenSource Code for Computing Earthquake Rates in Fault Systems and Constructing Hazard Models. Seismological Research Letters, 90(4), 1678-1688. DOI: https://doi. org/10.1785/0220180332

Childs, C., Manzocchi, T., Walsh, J.J., Bonson, C.G., Nicol, A., Schöpfer, M.P.J., 2009. A geometric model of fault zone and fault rock thickness variations. Journal of Structural Geology, 31(2), 117-127. DOI: https://doi.org/10.1016/j. jsg.2008.08.009

Cowie, P.A., Roberts, G.P., Bull, J.M., Visini, F, 2012. Relationships between fault geometry, slip rate variability and earthquake recurrence in extensional settings. Geophysical Journal International, 189(1), 143-160. DOI: https://doi.org/10.1111/ j.1365-246X.2012.05378.x

Crone, A.J., Haller, K.M., 1991. Segmentation and the coseismic behavior of Basin and Range normal faults: examples from east-central Idaho and southwestern Montana, U.S.A. Journal of Structural Geology, 13(2), 151-164. DOI: https://doi. org/10.1016/0191-8141(91)90063-O

Delgado, F, 1978. Los Alpujarrides en Sierra de Baza (Cordilleras Béticas, España). PhD Thesis. University of Granada. 483pp.

De Martini, P.M., Hessami, K., Pantosti, D., D’Addezio, G., Alinaghi, H., Ghafory-Ashtiani, M., 1998. A geologic contribution to the evaluation of the seismic potential of the Kahrizak fault (Tehran, Iran). Tectonophysics, 287(1-4), 187-199. DOI: https://doi.org/10.1016/S00401951(98)80068-1

DeMets, C., Gordon, R.G., Argus, D.F., 2010. Geologically current plate motions. Geophysical Journal International, 181(1), 1-80. DOI: https://doi.org/10.1111/j.1365-246X.2009.04491.x

Deng, C., Gawthorpe, R.L., Finch, E., Fossen, H., 2017. Influence of a pre-existing basement weakness on normal fault growth during oblique extension: Insights from discrete element modeling. Journal of Structural Geology, 105, 44-61. DOI: https://doi.org/10.1016/j.jsg.2017.11.005
Díaz-Hernández, J.L., Julià, R., 2006. Geochronological position of badlands and geomorphological patterns in the GuadixBaza basin (SE Spain). Quaternary Research, 65(3), 467-477. DOI: https://doi.org/10.1016/j.yqres.2006.01.009

Fairley, J.P., 2009. Modeling fluid flow in a heterogeneous, faultcontrolled hydrothermal system. Geofluids, 9(2), 153-166. DOI: https://doi.org/10.1111/j.1468-8123.2008.00236.x

Ferril., D.A., Morris, A.P., McGinnis, R.N., Smart, K.J., Wigginton, S.S., Hill, N.J., 2017. Mechanical stratigraphy and normal faulting. Journal of Structural Geology, 94, 275-302. DOI: https://doi.org/10.1016/j.jsg.2016.11.010

Field, E.H., Johnson, D.D., Dolan, J.F., 1999. A mutually consistent seismic-hazard source model for southern California. Bulletin of the Seismological Society of America, 89(3), 559-578.

Field, E.H., Biasi, G.P., Bird, P., Dawson, T.E., Felzer, K.R., Jackson, D.D., Johnson, K.M., Jordan, T.H., Madden, C., Michael, A. J., Milner, K.R., Page, M.T., Parsons, T., Powers, P.M., Shaw, B.E., Thatcher, W.R., Weldon, R.J., Zeng, Y., 2015. Long-term time-dependent probabilities for the third Uniform California Earthquake Rupture Forecast (UCERF3). Bulletin of the Seismological Society of America, 105(2A), 511-543. DOI: https://doi. org/10.1785/0120140093

Folch, A., Mas-Pla, J., 2008. Hydrogeological interactions between fault zones and alluvial aquifers in regional flow systems. Hydrological Processes, 22(17), 3476-3487. DOI: https://doi. org/10.1002/hyp.6956

Fossen, H., Rotevatn, A., 2016. Fault linkage and relay structures in extensional settings - A review. Earth-Science Reviews, 154, 14-28. DOI: https://doi.org/10.1016/j.earscirev.2015.11.014

Galindo-Zaldívar, J., González-Lodeiro, F, Jabaloy, A., 1989. Progressive extensional shear structures in a detachment contact in the Western Sierra Nevada (Betic Cordilleras, Spain). Geodinamica Acta, 3(1), 73-85. DOI: https://doi.org/ 10.1080/09853111.1989.11105175

Galindo-Zaldívar, J., González-Lodeiro, F., Jabaloy, A., 1993. Stress and palaeostress in the Betic-Rif cordilleras (Miocene to the present). Tectonophysics, 227(1-4), 105-126. DOI: https://doi. org/10.1016/0040-1951(93)90090-7

Galindo-Zaldívar, J., Jabaloy, A., González-Lodeiro, F., Aldaya, F, 1997. Crustal structure of the central sector of the Betic Cordillera (SE Spain). Tectonics, 16(1), 18-37. DOI: https:// doi.org/10.1029/96TC02359

Galindo-Zaldívar, J., Jabaloy, A., Serrano, I., Morales, J., GonzálezLodeiro, F, Torcal, F., 1999. Recent and present-day stresses in the Granada Basin (Betic Cordilleras): Example of a late Miocene-present-day extensional basin in a convergent plate boundary. Tectonics, 18(4), 686-702. DOI: https://doi. org/10.1029/1999TC900016

Galindo-Zaldívar, J., Gil, A.J., Sanz de Galdeano, C., Lacy, M.C., García-Armenteros, J.A., Ruano, P., Ruiz, A.M., MartínezMartos, M., Alfaro, P., 2015. Active shallow extension in central and eastern Betic Cordillera from CGPS data. Tectonophysics, 663, 290-301. DOI: https://doi.org/10.1016/j. tecto.2015.08.035 
García-Aguilar, J.M., Martín, J.M., 2000. Late Neogene to recent continental history and evolution of the Guadix-Baza basin (SE Spain). Revista de la Sociedad Geológica de España, 13(1), 65-77.

García-Aguilar, J.M., Palmqvist, P., 2011. A model of lacustrine sedimentation for the Early Pleistocene deposits of Guadix-Baza basin (southeast Spain). Quaternary International, 243(1), 3-15. DOI: https://doi.org/10.1016/j. quaint.2011.02.008

García-Dueñas, V., Balanyá, J.C., Martínez-Martínez, J.M., 1992. Miocene extensional detachments in the outcropping basement of the northern Alboran Basin (Betics) and their tectonic implications. Geo-Marine Letters, 12, 88-95. DOI: https://doi.org/10.1007/BF02084917

García-García, F., Fernández, J., Viseras, C., Soria, J.M., 2006. Architecture and sedimentary facies evolution in a delta stack controlled by fault growth (Betic Cordillera, southern Spain, late Tortonian). Sedimentary Geology, 185(1-2), 79-92. DOI: https://doi.org/10.1016/j.sedgeo.2005.10.010

García-Hernández, M., López-Garrido, A.C., Rivas, P., Sanz de Galdeano, C., Vera, J.A., 1980. Mesozoic palaeogeographic evolution of the External Zones of the Betic Cordillera. Geologie en Mijnbouw, 59(2), 155-168. ISSN: 0016-7746

García-Tortosa, FJ., Sanz de Galdeano, C., Alfaro, P., GalindoZaldívar, J., Peláez, J.A., 2007. La falla y los pliegues de Galera. In: Sanz de Galdeano, C., Peláez, J.A. (eds.). La cuenca de Guadix-Baza: estructura, tectónica activa, sismicidad, geomorfología y dataciones existentes. Universidad de Granada, 141-153.

García Tortosa, FJ., Alfaro, P., Galindo Zaldívar, J., Gibert, L., López Garrido, A.C., Sanz de Galdeano, C., Ureña, M., 2008. Geomorphologic evidence of the active Baza fault (Betic Cordillera, South Spain). Geomorphology, 97(3-4), 374-391. DOI: https://doi.org/10.1016/j.geomorph.2007.08.007

García-Tortosa, FJ., Alfaro, P., Galindo Zaldívar, J., Sanz de Galdeano, C., 2011. Glacis geometry as a geomorphic marker of recent tectonics: the Guadix-Baza Basin (South Spain). Geomorphology, 125(4), 517-529. DOI: https://doi. org/10.1016/j.geomorph.2010.10.021

Giba, M., Walsh, J.J., Nicol, A., 2012. Segmentation and growth of an obliquely reactivated normal fault. Journal of Structural Geology, 39, 253-267. DOI: https://doi.org/10.1016/j. jsg.2012.01.004

Gibert, L., Ortí, F., Rosell, L., 2007a. Plio-Pleistocene lacustrine evaporites of the Baza Basin (Betic Chain, SE Spain). Sedimentary Geology, 200(1-2), 89-116. DOI: https://doi. org/10.1016/j.sedgeo.2007.03.003

Gibert, L., Scott, G., Martin, R., Gibert, J., 2007b. The Early to Middle Pleistocene boundary in the Baza Basin (Spain). Quaternary Science Reviews, 26(17-18), 2067-2089. DOI: https://doi.org/10.1016/j.quascirev.2007.06.012

Gil, A.J., Rodríguez-Caderot, G., Lacy, M.C., Ruiz, A.M., Sanz de Galdeano, C., Alfaro, P., 2002. Establishment of a NonPermanent GPS Network to Monitor the Recent NE-SW
Deformation in the Granada Basin (Betic Cordillera, Southern Spain). First Results from a non-permanent GPS network. Studia Geophysica et Geodaetica, 46, 395-409. DOI: https:// doi.org/10.1023/A:1019530716324

Goy, J.L., Zazo, C., Dabrio, C.J., Hoyos, M., Civis, J., 1989. Geomorfología y evolución dinámica del sector suroriental de la cuenca de Guadix-Baza (área Baza-Caniles). Trabajos sobre el Neógeno-Cuaternario, 11, 97-111. ISSN: 0210-5217

Grünthal, G., 1998. European Macroseismic Scale 1998. Luxembourg: Conseil de l'Europe, Cahiers du Centre Europèen de Gèodynamique et de Seismologie, 15, 100pp.

Guerra-Merchán, A., 1992. Origen y relleno sedimentario de la cuenca neógena del corredor del Almanzora y áreas limítrofes (Cordillera Bética). PhD Thesis. University of Granada, 237pp.

Guerra-Merchán, A., Ruíz-Bustos, A., Martín-Penela, A.J., 1991. Geología y fauna de los yacimientos de Colorado 1, Colorado 2, Aljibe 2 y Aljibe 3 (Cuenca de Guadix-Baza, Cordilleras Béticas). Geogaceta, 9, 99-102.

Guerra-Merchán, A., Ruíz-Bustos, A., 1992. Nuevos datos bioestratigráficos de los materiales continentales del sector suroriental de la Cuenca de Guadix-Baza. El yacimiento de Caniles. Geogaceta, 11, 76-78. ISSN: 0213683X

Haberland, C., Giber, L., José Jurado, M., Stiller, M., BaumannWilke, M., Scott, G., Mertz, D.F., 2017. Architecture and tectono-stratigraphic evolution of the intramontane Baza Basin (Bétics, SE-Spain): Constraints from seismic imaging. Tectonophysics, 709, 69-84. DOI: https://doi.org/10.1016/j. tecto.2017.03.022

Herraiz, M., De Vicente, G., Lindo-Ñaurapi, R., Giner, J., Simón, J.L., González-Casado, J., Vadillo, O., Rodriguez-Pascua, M.A., Cicuéndez, J.L., Casas, A., Cabañas, L., Rincón, P., Cortés, A. L., Ramírez Lucini, M., 2000. The recent (upper Miocene to Quaternary) and present tectonic stress distributions in the Iberian Peninsula. Tectonics, 19(4), 762-786. DOI: https:// doi.org/10.1029/2000TC900006

Iezzi, F, Mildon, Z., Walker, J.F, Roberts, G., Goodwall, H., Maxwell., W., Robertson., J., 2018. Coseismic Throw Variation Across Along-Strike Bends on Active Normal Faults: Implications for Displacement Versus Length Scaling of Earthquake Ruptures. Journal of Geophysical Research: Solid Earth, 123, 98179841. DOI: https://doi.org/10.1029/2018JB016732

IGN-UPM, 2013. Actualización de mapas de peligrosidad sísmica de España 2012. Madrid, Centro Nacional de Información Geográfica, 267pp. ISBN: 978-84-416-2685-0

Jackson, C.A.L., Rotevatn, A., 2013. 3D seismic analysis of the structure and evolution of a salt-influenced normal fault zone: A test of competing fault growth models. Journal of Structural Geology, 54, 215-234. DOI: https://doi.org/10.1016/j. jsg.2013.06.012

Janecke, S.U., Vandenburg, C.J., Blankenau, J.J., 1998. Geometry, mechanisms and significance of extensional folds from examples in the Rocky Mountain Basin and Range province, U.S.A. Journal of Structural Geology, 20(7), 841-856. DOI: https://doi.org/10.1016/S0191-8141(98)00016-9 
Janecke, S.U., Dorsey, R.J., Forand, D., Steely, A.N., Kirby, S.M., Lutz, A.T., Housen, B.A., Belgarde, B., Langenheim, V.E., Rittenour, T.M., 2010. High geologic slip rates since Early Pleistocene initiation of the San Jacinto and San Felipe fault zones in the San Andreas Fault System: Southern California, USA. The Geological Society of America Special Paper, 475, 48pp.

Kobayashi, T., Tobita, M., Koarai, M., Okatani, T., Suzuki, A., Noguchi, Y., Yamanaka, M., Miyahara, B., 2012. InSARderived crustal deformation and fault models of normal faulting earthquake (Mj 7.0) in the Fukushima-Hamadori area. Earth Planets Space, 64, 1209-1221. DOI: https://doi. org/10.5047/eps.2012.08.015

Kurt, H., Sorlien, C.C., Seeber, L., Steckler, M.S., Shillington, D.J., Cifci, G., Cormier, M.H., Dessa, J.X., Atgin, O., Dondurur, D., Demirbag, E., Okay, S., Imren, C., Gurcay, S., Carton, H., 2013. Steady late Quaternary slip rate on the Cinarcik section of the North Anatolian fault near Istanbul, Turkey. Geophysical Research Letters, 40(17), 1-5. DOI: https://doi.org/10.1002/ grl.50882

Legg, M.R., Goldfinger, C., Kamerling, M.J., Chaytor, J.D., Einstein, D.E., 2007. Morphology, structure and evolution of California Continental Borderland restraining bends. In: Cunningham, W.D., Mann, P. (eds.). Tectonics of StrikeSlip Restraining and Releasing Bends. London, Geological Society, 290 (Special Publications), 143-168. DOI: https://doi. org/10.1144/SP290.3

Leonard, M., 2010. Earthquake fault scaling: Self-consistent relating of rupture length, width, average displacement, and moment release. Bulletin of the Seismological Society of America, 100(5A), 1971-1988. DOI: https://doi. org/10.1785/0120090189

Manzocchi, T., Childs, C., Walsh, J.J., 2010. Faults and fault properties in hydrocarbon flow models. Geofluids, 10(1-2), 94113. DOI: https://doi.org/10.1111/j.1468-8123.2010.00283.x

Marcén, M., Román-Berdiel, T., Casas-Sainz, A.M., Soto, R., Oliva-Urcia, B., Castro, J., 2019. Strain variations in a seismogenic normal fault (Baza Sub-basin, Betic Chain): Insights from magnetic fabrics (AMS). Tectonophysics, 765, 64-82. DOI: https://doi.org/10.1016/j.tecto.2019.05.014

Martín-Algarra, A., Andreo, B., Balany, J.C., Estévez, A., LópezGarrido, A.C., O’Dogherty, L., García-Dueñas, V., 2004. Unidades Frontales de las Zonas Internas. In: Vera, J.A. (ed.). Geología de España. Madrid, Sociedad Geológica de EspañaInstituto Geológico y Minero de España (SGE-IGME),, 396401.

Martin-Rojas, I., Somma, R., Delgado, F, Estévez, A., Iannace, A., Perrone, V., Zamparelli, V., 2009. Triassic continental rifting of Pangaea: direct evidence from the Alpujarride carbonates, Betic Cordillera, SE Spain. Journal of the Geological Society, 166(3), 447-458. DOI: https://doi.org/10.1144/001676492008-091

Martin-Rojas, I., Somma, R., Delgado, F, Estévez, A., Iannace, A., Zamparelli, V., 2012. The Triassic platform of the Gador-Turon unit (Alpujarride complex, Betic Cordillera, southeast Spain): climate versus tectonic factors controlling platform architecture. Facies, 58, 297-323. DOI: https://doi. org/10.1007/s10347-011-0275-Z

Martínez-Martínez, J.M., Booth-Rea, G., Azañón, J.M., Torcal, F, 2006. Active transfer fault zone linking a segmented extensional system (Betics, southern Spain): Insight into heterogeneous extension driven by edge delamination. Tectonophysics, 422(1-4), 159-173. DOI: https://doi. org/10.1016/j.tecto.2006.06.001

Martínez-Solares, J.M., Mezcua, J., 2002. Catálogo sísmico de la Península Ibérica (880 AC-1900). Madrid (Spain), Instituto Geográfico Nacional (IGN), Monografía no 18, 254pp.

Matthews, M.V., Ellsworth, W.L., Reasenberg, P.A., 2002. A Brownian model for recurrent earthquakes. Bulletin of the Seismological Society of America, 92(6), 2233-2250. DOI: https://doi.org/10.1785/0120010267

Medina-Cascales, I., Koch, L., Cardozo, N., Martin-Rojas, I., Alfaro, P., García-Tortosa, FJ., 2019. 3D geometry and architecture of a normal fault zone in poorly lithified sediments: A trench study on a strand of the Baza Fault, central Betic Cordillera, south Spain. Journal of Structural Geology, 121, 25-45. DOI: https://doi.org/10.1016/j.jsg.2019.02.003

Mildon, Z.K., Toda, S., Faure Walker, J.P., Roberts, G.P., 2016. Evaluating models of Coulomb stress transfer: Is variable fault geometry important? Geophysical Research Letters, 43(24), 12407-12414. DOI: https://doi.org/10.1002/2016GL071128

Mouslopoulou, V., Nicol, A., Little, T.A., Walsh, J.J., 2007. Displacement transfer between intersecting regional strikeslip and extensional fault systems. Journal of Structural Geology, 29(1), 100-116. DOI: https://doi.org/10.1016/j. jsg.2006.08.002

Nocquet, J-M., 2012. Present-day kinematics of the Mediterranean: A comprehensive overview of GPS results. Tectonophysics, 579, 220-242. DOI: https://doi.org/10.1016/j. tecto.2012.03.037

Olivera Serrano, C., 1995. La actividad sísmica en el reino de Granada (1487-1531): Estudio histórico y documentos. Madrid, Editorial Grafos 112pp.

Okada, Y., 1985. Surface deformation due to shear and tensile faults in a half-space. Bulletin of the Seismological Society of America, 75(4), 1135-1154.

Okada, Y., 1992. Internal deformation due to shear and tensile faults in a half-space. Bulletin of the Seismological Society of America, 82(2), 1018-1040.

Orozco, M., Alonso-Chaves, FM., 2002. Estructuras de colapso extensional en el Dominio de Alborán. In: Orozco, M. (ed.). Región de La Axarquía-Sierra Tejeda (provincias de Málaga y Granada). XIV Reunión de la Comisión de Tectónica de la Sociedad Geológica de España, Guía de Campo, Granada, 120pp. ISBN: 84-607-5712-9

Pace, B., Boncio, P., Lavecchia, G., 2002. The 1984 Abruzzo earthquake (Italy): an example of seismogenic process controlled by interaction between differently oriented synkinematic faults. Tectonophysics, 350(3), 237-254. DOI: https://doi.org/10.1016/S0040-1951(02)00118-X 
Pace, B., Visini, F., Peruzza, L., 2016. FiSH: MATLAB tools to turn fault data into Seismic-Hazard Models. Seismological Research Letters, 87(2A), 374-386. DOI: https://doi. org/10.1785/0220150189

Patel, J.K., Kapadia, C.H., Owen, D.B., 1976. Handbook of Statistical Distributions. New York, Marcel Dekker, 302pp.

Peacock, D.C.P., Anderson, M.W., 2012. The scaling of pull-aparts and implications for fluid flow in areas with strike-slip faults. Journal of Petroleum Geology, 35(4), 389-400. DOI: https:// doi.org/10.1111/j.1747-5457.2012.00537.x

Peacock, D.C.P., Nixon, C.W., Rotevatn, A., Sanderson, D.J., Zuluaga, L.F., 2016. Glossary of fault and other fracture networks. Journal of Structural Geology, 92, 12-29. DOI: https://doi.org/10.1016/j.jsg.2016.09.008

Peacock, D.C.P., Nixon, C.W., Rotevatn, A., Sanderson, D.J., Zuluaga, L.F, 2017a. Interacting faults. Journal of Structural Geology, 97, 1-22. DOI: https://doi.org/10.1016/j.jsg.2017.02.008

Peacock, D.C.P., Dimmen, V., Rotevatn, A., Sanderson, D.J., 2017 b. A broader classification of damage zones. Journal of Structural Geology, 102, 179-192. DOI: https://doi.org/10.1016/j. jsg.2017.08.004

Pedrera, A., 2008. Structure and tectonic evolution of the Almanzora corridor and the western Huércal-Overa basin (Eastern Betic Cordillera). PhD Thesis. University of Granada, 201pp.

Pedrera, A., Galindo-Zaldívar, J., Sanz de Galdeano, C., LópezGarrido, A.C., 2006. Superposición de fallas y paleoesfuerzos en el Corredor del Almanzora desde el Tortoniense a la actualidad (Cordilleras Béticas). Geogaceta, 39, 59-62. ISSN: 0213683X

Pedrera, A., Galindo-Zaldívar, J., Marín-Lechado, C., GarcíaTortosa, FJ., Ruano, P., López Garrido, A.C., Azañón, J.M., Peláez, J.A., Giaconia, F., 2012. Recent and active faults and folds in the central-eastern Internal Zones of the Betic Cordillera. Journal of Iberian Geology, 38(1), 191-208. DOI: https://doi.org/10.5209/rev_JIGE.2012.v38.n1.39213

Peña, J., 1979. La depresión de Guadix-Baza: Estratigrafía del Plioceno-Pleistoceno. PhD Thesis. University of Granada, $179 \mathrm{pp}$.

Peña, J.A., 1985. La depresión de Guadix-Baza. Estudios Geológicos, 41(1-2), 33-46. DOI: https://doi.org/10.3989/ egeol.85411-2688

Peña, J.A., Rodríguez-Fernández, J., Ruiz-Bustos, A., 1977. El yacimiento de vertebrados de cortes de Baza I (Depresión de Guadix-Baza). Nota preliminar. Acta Geológica Hispánica, XII, 42-45.

Pérez-Peña, V., Azañón, J.M., Azor, A., Tuccimei, P., Della Seta, M., Soligo, M., 2009. Quaternary landscape evolution and erosion rates for an intramontane Neogene basin (GuadixBaza basin, SE Spain). Geomorphology, 106(3-4), 206-218. DOI: https://doi.org/10.1016/j.geomorph.2008.10.018

Pérez-Peña, A., Martín-Dávila, J., Gárate, J., Berrocoso, M., Buforn, E., 2010. Velocity field and tectonic strain in Southern Spain and surrounding areas derived from GPS episodic measurements. Journal of Geodynamics, 49(3-4), 232-240. DOI: https://doi.org/10.1016/j.jog.2010.01.015
Rice, J.R., Cocco, M., 2007. Seismic fault rheology and earthquake dynamics. In: Handy, M.R., Hirth, G., Hovious, N. (eds.). The Dynamics of Fault Zones. Cambridge, MIT Press, 99-137.

Rockwell, T., Ragona, D., Seitz, G., Langridge, R., Aksoy, M.E., Ucarkus, G., Ferry, M., Meltzner, A.J., Klinger, Y., Meghraoui, M., Satir, D., Barka, A., Akbalik, B., 2009. Palaeoseismology of the North Anatolian Fault near the Marmara Sea: implications for fault segmentation and seismic hazard. In: Reicherter, K., Michetti, A.M., Silva, P.G. (eds.). Palaeoseismology: Historical and Prehistorical Records of Earthquake Ground Effects for Seismic Hazard Assessment. London, Geological Society, 316 (Special Publications), 31-54. DOI: https://doi. org/10.1144/SP316.3

Ros-Montoya, S., Martínez-Navarro, B., Espigares, M.P., GuerraMerchán, A., García-Aguilar, J.M., Piñero, P., RodríguezRueda, A., Agustí, J., Oms, O., Palmqvist, P., 2017. A new Ruscinian site in Europe: Baza-1 (Baza basin, Andalusia, Spain). Comptes Rendus Palevol, 16(7), 746-761. DOI: https://doi.org/10.1016/j.crpv.2017.05.005

Ruiz, A.M., Ferhat, G., Alfaro, P., Sanz de Galdeano, C., Lacy, M.C., Rodríguez-Caderot, G., Gil, A.J., 2003. Geodetic Measurement of Crustal Deformation on NW-SE Faults of The Betic Cordillera, Southern Spain, 1999-2001. Journal of Geodynamics, 35(3), 259-272. DOI: https://doi.org/10.1016/ S0264-3707(02)00134-5

Saltzer, S.D., Polland, D.D., 1992. Distinct element modelling of structures formed in sedimentary overburden by extensional reactivation of basement normal faults. Tectonics, 11(1), 165174. DOI: https://doi.org/10.1029/91TC02462

Sanz de Galdeano, C., Alfaro, P., 2004. Tectonic significance of the present relief of the Betic Cordillera. Geomorphology, 63(3-4), 175-190. DOI: https://doi.org/10.1016/j. geomorph.2004.04.002

Sanz de Galdeano, C., García-Tortosa, FJ., Peláez, J.A., Alfaro, P., Azañón, J.M., Galindo-Zaldívar, J., López-Casado, C., LópezGarrido, A.C., Rodríguez-Fernández, J., Ruano, P., 2012. Main active faults in the Granada and Guadix-Baza Basins (Betic Cordillera). Journal of Iberian Geology, 38(1), 209-223. DOI: 10.5209/rev_JIGE.2012.v38.n1.39215

Sanz de Galdeano, C., Azañón, J.M., Cabral, J., Ruano, P., Alfaro, P., Canora, C., Ferrater, M., García-Tortosa, F., Mayordomo, J., Gràcia, E., Insua-Arévalo, J.M., Jiménez, A., Lacan, P., Marín-Lechado, C., Martín-Banda, R., Martín-González, F., Martinez-Diaz, J.J., Martin-Rojas, I., Masana, E., Simón, J.L., 2020. Active Faults in Iberia. In: Quesada, C., Oliveira, J. (eds.). The Geology of Iberia: A Geodynamic Approach. Cham, Regional Geology Reviews, Springer, 33-75.

Scholz, C.H., 2002. The mechanics of Earthquakes and Faulting. Cambridge, Cambridge University Press, 487pp.

Scott, G.R., Gibert, L., 2009. The oldest hand-axes in Europe. Nature, 461, 82-85. DOI: https://doi.org/10.1038/nature08214

Serpelloni, E., Vannucci, G., Pondrelli, S., Argnani, A., Casula, G., Anzidei, M., Balde, P., Gasperini, P., 2007. Kinematics of the Western Africa-Eurasia plate boundary from focal mechanisms and GPS data. Geophysical Journal International, 
169(3), 1180-1200. DOI: https://doi.org/10.1111/j.1365246X.2007.03367.x

Soria, FJ., López-Garrido, A.C., Vera, J.A., 1987. Análisis estratigráfico y sedimentológico de los depósitos neógenocuaternarios en el sector de Orce (depresión de GuadixBaza). Paleontologia i Evolució, Memòria Especial, 1, 11-34.

Sparacino, F., Palano, M., Peláez, J.A., Fernández, J., 2020. Geodetic Deformation versus Seismic Crustal Moment-Rates: Insights from the Ibero-Maghrebian Region. Remote Sensing, 12(6), 952. DOI: https://doi.org/10.3390/rs12060952

Stich, D., Benito Martín, J., Morales, J., 2007. Deformación sísmica y asísmica en la zona Béticas-Rif-Alborán. Revista de la Sociedad Geológica de España, 20(3-4), 311-319.

Stirling, M., Rhoades, D., Berryman, K., 2002. Comparison of Earthquake Scaling Relations Derived from Data of the Instrumental and Preinstrumental Era. Bulletin of the Seismological Society of America, 92(2), 812-830. DOI: https://doi.org/10.1785/0120000221

Sun, J., Shen, Z., Xu, X., Bürgman, R., 2008. Synthetic normal faulting of the 9 January 2008 Nima (Tibet) earthquake from conventional and along-track SAR interferometry. Geophysical Research Letters, 35, L22308. DOI: https://doi. org/10.1029/2008GL035691

Toda, S., Stein, R.S., Sevilgen, V., Lin, J., 2011 Coulomb 3.3 Graphic-rich deformation and stress-change software for earthquake, tectonic, and volcano research and teaching - user guide. U.S. Geological Survey Open-File Report, 2011-1060, 63pp. Available at: https://pubs.usgs.gov/of/2011/1060/ Last accessed: 30/01/2020

Vera, J.A., 1970a. Facies del Plioceno de la Depresión de GuadixBaza. Cuadernos Geológicos de la Universidad de Granada, 1, 23-25.

Vera, J.A., 1970b. Estudio estratigráfico de la Depresión de Guadix-Baza. Boletín del Instituto Geológico y Minero de España, 81, 429-462.
Vera, J.A., Rodriguez, J., Guerra, A., Viseras, C., 1994. La Cuenca de Guadix-Baza. Documents et Travaux de l' Institut géologique Albert de Lapparent, 14, 1-17.

Viseras, C.A., 1991. Estratigrafía y sedimentología del relleno aluvial de la cuenca de Guadix (Cordilleras Béticas). PhD Thesis. University of Granada, 327pp.

Wells, D.L., Coppersmith K.J., 1994. New empirical relationships among magnitude, rupture length, rupture width, rupture area, and surface displacement. Bulletin of the Seismological Society of America, 84(4), 974-1002.

Wesnousky, S.G., 1986. Earthquakes, quaternary faults, and seismic hazard in California. Journal of Geophysical Research: Solid Earth, 91(B12), 12587-12631. DOI: https://doi.org/10.1029/ JB091iB12p12587

Wesnousky, S.G., 2006. Predicting the endpoints of earthquake ruptures. Nature, 444, 358-360. DOI: https://doi.org/10.1038/ nature 05275

Wesnousky, S.G., 2008. Displacement and Geometrical Characteristics of Earthquake Surface Ruptures: Issues and Implications for Seismic-Hazard Analysis and the Process of Earthquake Rupture. Bulletin of the Seismological Society of America, 98(4), 1609-1632. DOI: https://doi. org/10.1785/0120070111

Whipp, P.S., Jackson, C.A-L., Gawthorpe, R.L., Dreyer, T., Quinn, D., 2013. Normal fault array evolution above a reactivated rift fabric; a subsurface example from the northern Horda Platform, Norwegian North Sea. Basin Research, 26(4), 523549. DOI: https://doi.org/10.1111/bre.12050

Wibberley, C.A.J., Gonzalez-Dunia, J., Billon, O., 2017. Faults as barriers or channels to production-related flow: Insights from case studies. Petroleum Geoscience, 23(1), 134-147. DOI: https://doi.org/10.1144/petgeo2016-057

\section{Manuscript received April 2020; \\ revision accepted July 2020; \\ published Online July 2020.}

